\title{
İstanbul Hanlar Bölgesi'nde Yer Alan Yarım Han'ın Restorasyon Projesinin Tarihi Belgelere Dayanarak Hazırlanması
}

\author{
Seda ÖZTEKİN ${ }^{1 *}$ \\ ${ }^{1}$ Haliç Üniversitesi, İç Mimarlık Bölümü, İstanbul, Türkiye \\ *Sorumlu Yazar e mail: sedaoztekin@halic.edu.tr \\ Geliş Tarihi: 05.08 .2020 \\ Kabul Tarihi: 18.09 .2020 \\ Atıf/Citation: Öztekin, S. “İstanbul Hanlar Bölgesi’nde Yer Alan Yarım Han'ın Restorasyon Projesinin \\ Tarihi Belgelere Dayanarak Hazırlanması”, Haliç Üniversitesi Fen Bilimleri Dergisi 2020, 3/2: 241-288. \\ Derleme Makalelele/Review Articles
}

\section{Özet}

İstanbul Tarihi Yarımada sınırları içerisinde yüzyıllar boyunca ticaret alanı olan 'Hanlar Bölgesi', ticari işlevin sürekliliğini sağlayan Han ve Kervansaray yapılarının inşa edilmesi ile, bölge kimliği oluşmuştur. Osmanlı döneminde çarşı kültürü kentin kalbinin attığı merkezler olmuşlardır. Son elli yıl içerisinde ise 'Hanlar Bölgesi'nin kent merkezi olma özelliğinden uzaklaştığı, sosyal ve fiziksel anlamda bozulmaya başladığı gözlemlenebilmektedir. Bu tanımlı alan içerisinde zaman içerisinde değişen sosyo-ekonomik etkenlerle birlikte koruma anlamında da ve özellikle yeniden işlevlendirme konusuna dair sorunların görüldüğü söylenebilir. Çalışmanın amacı, tanımlı alan içerisinde yer alan ve özgün işlevini sürdüren Yarım Han'ın ilgili kurumlarca onaylanmış rölöve, restitüsyon ve restorasyon projelerinin hazırlanması esnasında kullanılan yöntem ve önerilerin belgelenmesini içerir. Buna göre bu çalışmada yer alan yapının, yapısal ve çevresel faktörleri bir arada gözetilerek, özgün işlevine uygun bir restorasyon projesinin hazırlanması doğrultusunda sonuçlanması amaçlanmaktadır.

Anahtar Kelimeler: Koruma, Restorasyon, Hanlar Bölgesi, Yarım Han. 


\title{
The Preparation of Yarım Khan's Restoration Project in İstanbul Khans Region based on Historical Documents
}

\begin{abstract}
The 'Khans Region' which has been a commercial area for centuries within the borders of the Historic Peninsula of Istanbul, has created a regional identity with the construction of the Kahn and Caravanserai buildings that provide the continuity of the commercial function. In the Ottoman period, the bazaar culture became the centers of the heart of the city. In the last fifty years, it can be observed that the 'Khans Region' has moved away from being a city center and started to deteriorate socially and physically. In this defined area, it can be said that along with socio- economic factors that change over time, there are also problems related to conservation and especially to the re-functioning issue. The aim of the study includes the documentation of the methods and suggestions used in the preparation of the survey, restitution and restoration projects, approved by related institutions, of the Yarım Han, which is located within the defined area and maintains its original function. Accordingly, the structure in this study is aimed to be concluded in line with the preparation of a restoration project in accordance with its original function by considering the structural and environmental factors together.
\end{abstract}

Keywords: Conservation, Restoration, Khans Region, Yarım Khan.

\section{Giriş}

Kent imgesini oluşturan, benlik ve kimlik sahibi taşınmaz kültür varlıkları, yaşanmışlık hissi ile çevresinde yaşayanlar için hafıza mekânları oluştururlar. Kentsel koruma bütünlüğü içerisindeki pek çok değerden biri olan aidiyet duygusu kavramı, halkın kent içinde varlığını destekleyici niteliğindedir. Aynı şekilde, hafıza mekânlarının oluşması ile olduğu yere ait hissetme duygusu birbirinden ayrı düşünülemez. Farklı işlevlere sahip kültür varlıkları, kentsel planlama içerisinde belli alanlarda ağırlıklı olarak bir arada bulunmaktadırlar. Ticaret alanları ve bu alanlar içinde yer alan yapılar, dönem özellikleri, tekniği, plan ve cephe özellikleri bakımından farklılık göstererek belge değeri oluştururlar. Osmanlı şehrinde, konut alanları, ticaret ve yönetim alanları 
ile dini- kültürel alanlar bulunmaktadır. 'Osmanlı șehrinin doku özellikleri incelendiğinde, çarşı kültürünün kent sakinlerini bir araya getiren, birleştiren özelliği dikkat çekmektedir. Osmanlı kentinde ticaret alanları, konutları dışarda bırakarak, dükkân ve atölyelerin sıralandığı bir veya birden fazla sokaktan oluşan bir alanda yoğunlaşır. Çarşıyı oluşturan yapı taşları dükkânlardır. Dükkânların bir araya gelişş şekillerine göre arasta, bedesten ya da hanlar oluşur. Hanlar genellikle iki katlı, direkli ve kemerli bir galeri ile çevrelenmiş, kare veya dikdörtgen bir avlu etrafinda toplanmış odaların oluşturduğu ticaret ya da geçici konaklama yapılarıdır. Eminönü Hanları 15-19. yüzyıl arasında üç farklı tipte inşa edilmişlerdir. Bunlar; ticaret hanları(15-19. yüzyılların ilk yarıs1), büro hanları (19. yüzyıl sonu 20. yüzyıl baş1?) ve geçiş hanlarıdır (19. yüzyıl).' 1 '19.yüzyıl ortalarına kadar başta İstanbul' da olmak üzere Osmanlı İmparatorluğu'nun ticaret yapılan bütün şehirlerinde inşa edilen hanlar Klasik Osmanlı Ticaret Hanı kavramıyla tanınır. Fatih devri ile başlayıp 20.yüzyılın bașına kadar devam eden han mimarisi 19.yüzyılın başından önce? duraklamış ancak yüzyıl sonralarına doğru sosyal, ekonomik ve ticaret hayatındaki gelişmeler sonucunda giderek ticari hayatın iş yerleri, büroları halini almaya başlamışlardır.' 2

$\mathrm{Bu}$ araştırmaya konu olan Yarım Han, ticari fonksiyonun en yoğun olduğu Eminönü Hanlar Bölgesinde, özgün işlevini sürdürmekte olup, nitelikli bir örnek olma özelliğine sahiptir. İstanbul İli, Fatih İlçesi, 322 Ada 34/5 parsellerde bulunan Yarım Han, 26.01.2005 y1lında tescillenmiştir. Yapıyı çevreleyen Mahmutpaşa Yokuşu Sokağı ve Bezciler Sokağı'ndan olmak üzere iki ayrı girişi vardır. Köşe parselde konumlanan yapı, arazinin eğiminden dolayı Mahmutpaşa Yokuşu Sokağı tarafından üç, Bezciler Sokak tarafında iki katlıdır. Yapının yapım tarihine ilişkin, yapılan kapsamlı araştırmalar ile, bölgeye

1 ÖZKAN, A. 'Eminönü Hanlar Bölgesinin Cumhuriyet'ten Günümüze İzlenen Değișimi ve Yeniden Değerlendirilmesinde Öncelikli Bölgenin Saptanması'. Yüksek Lisans Tezi, İstanbul Teknik Üniversitesi, İstanbul, 2004.

2 Köroğlu, N. 'XIX. Yüzyıl ve XX. Yüzyıl Başı Eminönü’nde Osmanlı Büro Hanları'. Yüksek Lisans Tezi, Yıldız Teknik Üniversitesi, İstanbul, 2004. 
ait eski haritaların ve ticaret yıllıklarının incelenmesi sonucu 18891890 yılları arasında inşa edilmiş olduğu sonucuna ulaşılmıştır. Yapıldığ1 yıllara göre, geçiş hanı olma özelliğine sahip olduğu gözlenmektedir. '19. yüzyılda değişen kent ekonomilerine bağlı olarak han mimarisindeki klasik anlayış değişmiştir. İşlevlerdeki değişim teknolojik gelişmelerin de etkisiyle hanlara farklı plan şemaları ve yapım biçimlerini getirmiştir. Çoğu büro hanının zemin katı mağaza veya dükkânlara ayrılmış, ticaret hanlarında görülen içe dönük sade yapı, büro hanlarında yerini açık bezemeli cephelere bırakmıştır. 18. yüzyıldan itibaren görülmeye başlanan Batı etkisi bu dönemdeki hanlarda iyice kendini göstermiş mimari dekorasyon cephelerde ağırlık kazanmiştır.' 3

Mevcut kullanımının ticari olması, yapı işlevini sürdürür olması açısından olumlu bir özellik iken, günümüz ekonomik ve sosyal yapılanmadaki değişiklikten ötürü niteliksiz pek çok onarım ve eke sahiptir. Yapının restorasyon projesinin hazırlanması sırasında, öncelikle bölge ile ilgili detaylı literatür araştırması yapılmıştır. Belgeleme çalışmaları tamamlandıktan sonra, restitüsyon önerisi ve ardından restorasyon projesi hazırlanmıştır. İlgili kurumlarca incelemesi yapılan projeler onaylanmıştır. ${ }^{4}$

\section{Materyal ve Metot}

Bu çalışmada; literatür ve arşiv araştırmasının yapılmasının ardından, alanda yapılan ölçüm ve fotoğraflar neticesinde yapının belgelemesi yapılmıştır. Malzeme ve hasar tespitlerinin gösterildiği bir analiz ça1ışması eklenmiştir (Şekil 1, Şekil 2, Şekil 3, Şekil 4). Çağdaşı yapıların yapım sistemleri incelenmiş, benzer plan şemasına sahip diğer han yapılarına ait örnekler ile karşılaştırılmıştır. Buna göre, yapının

3 Gülenaz N. 'Batılılaşma dönemi İstanbul'unda Hanlar ve Pasajlar',İTO Yayınları, İstanbul,2010.

4 Yapının rölöve, restitüsyon ve restorasyon projeleri AS Mimarlık ve Restorasyon Ofisi kurucusu olarak tarafımca yapılmış olup, İstanbul IV Numaralı Kültür Varlıklarını Koruma Bölge Kurulu ve Fatih Belediyesi İmar ve Şehircilik Müdürlügünce 22.01.2016, 09.06.2017 ve 06.11.2017 tarihlerinde onaylanmıştır. 
restitüsyon önerisi hazırlanarak, özgün işlevini sürdürdüğü bir restorasyon projesi geliştirilmiştir. Restorasyon aşamasında yapılacak olan müdahaleler, belgeleme çalışması esnasında yapılan hasar tespitlerin giderilmesi yönündeki önceliği sağlayarak, kullanıcıların güncel ihtiyaçları doğrultusundaki talepleri de karşılık bulmuştur.

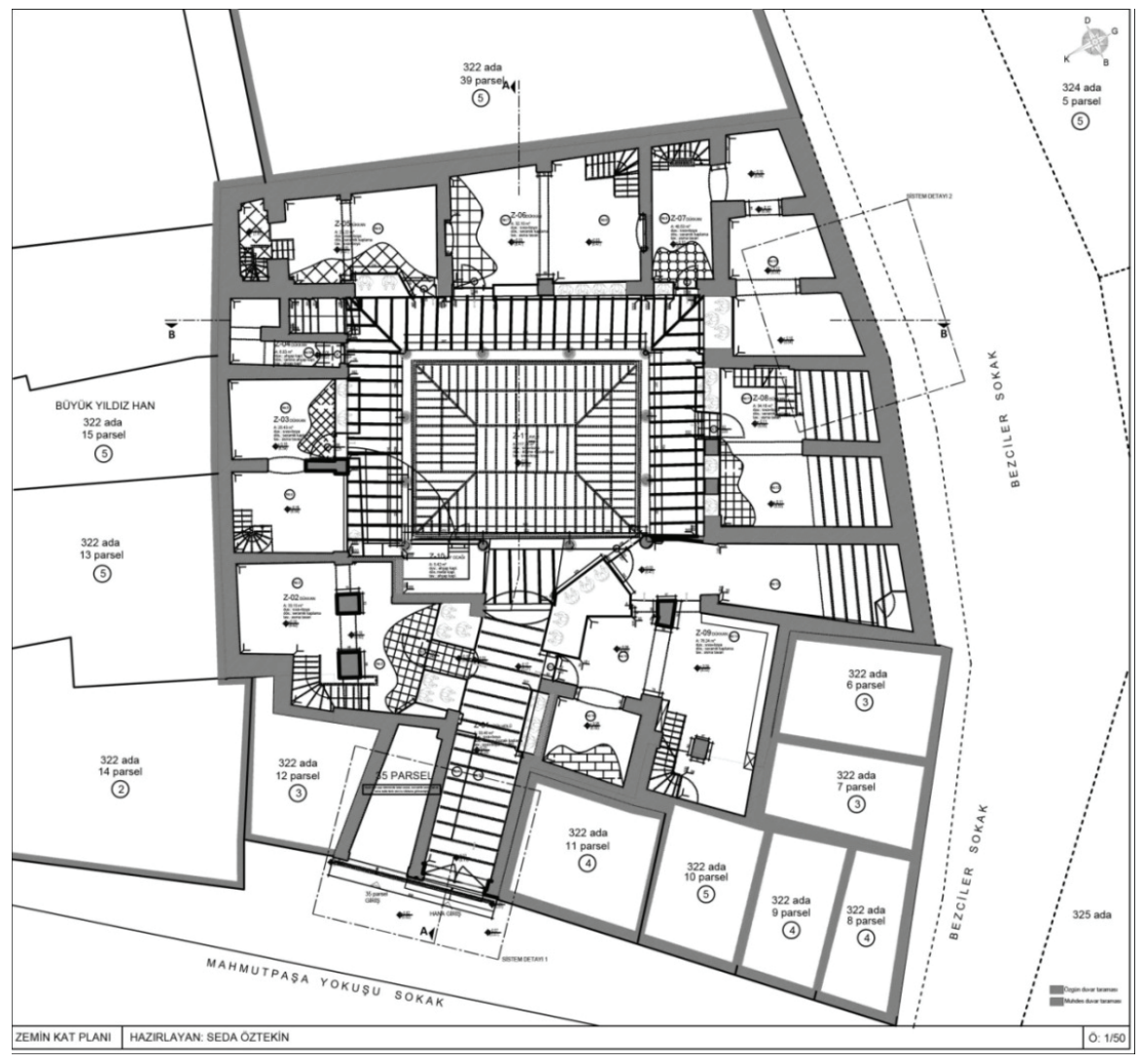

Şekil 1. Yarım Han Zemin Kat Rölövesi (Öztekin, 2016). 


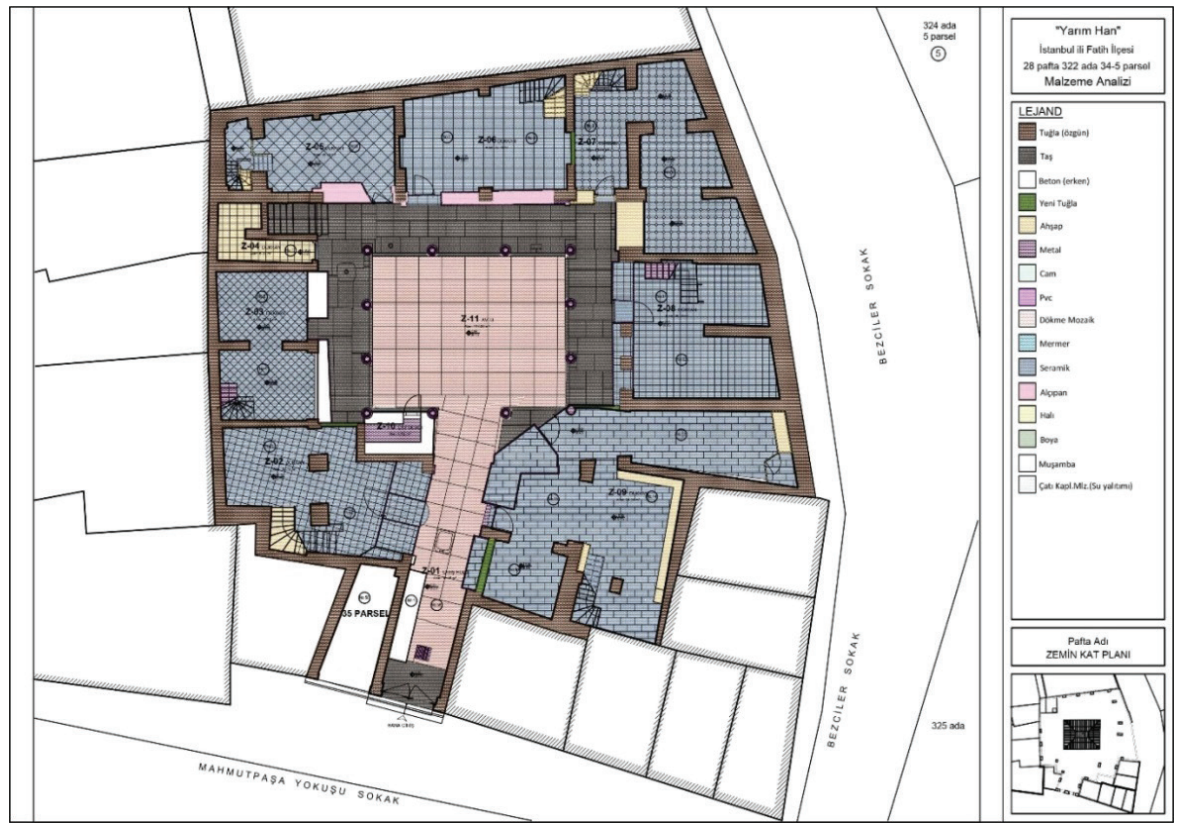

Şekil 2. Yarım Han Zemin Kat Planı Malzeme Analizi (Öztekin, 2016).

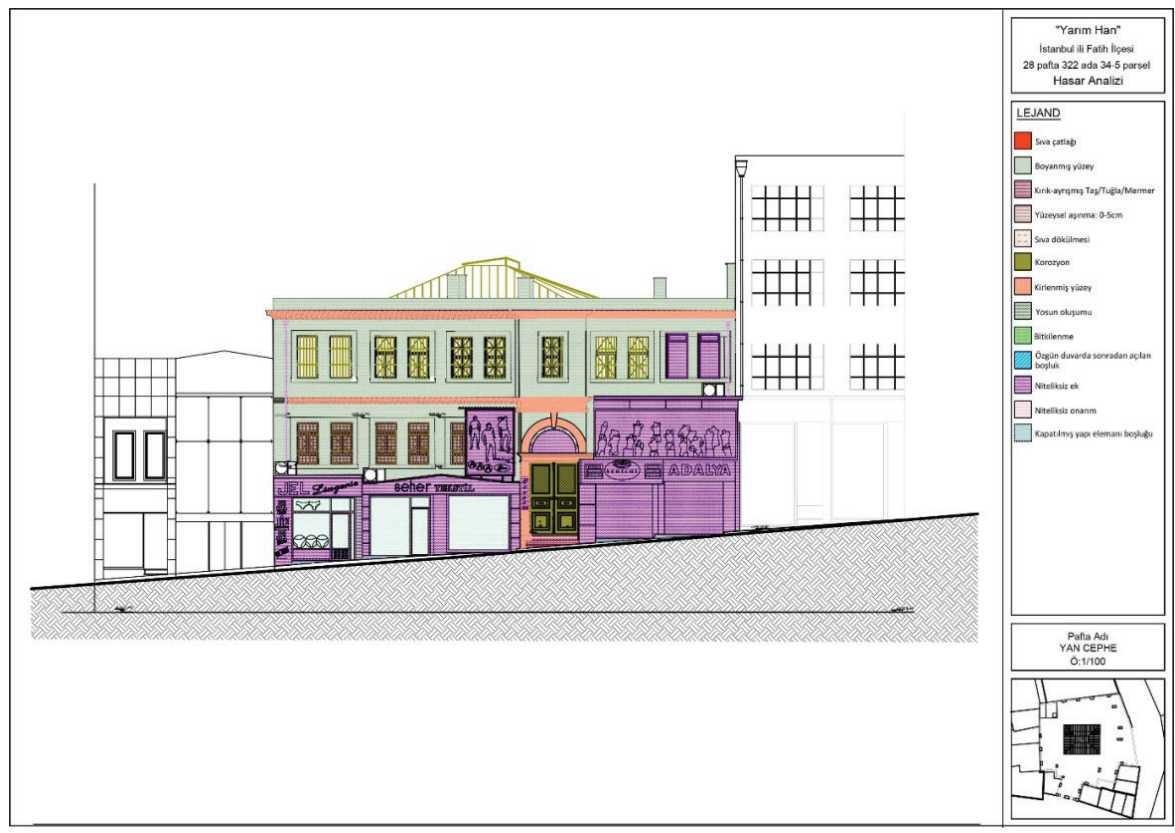

Şekil 3. Yarım Han Bezciler Sokak Cephesi Hasar Analizi (Öztekin, 2016). 


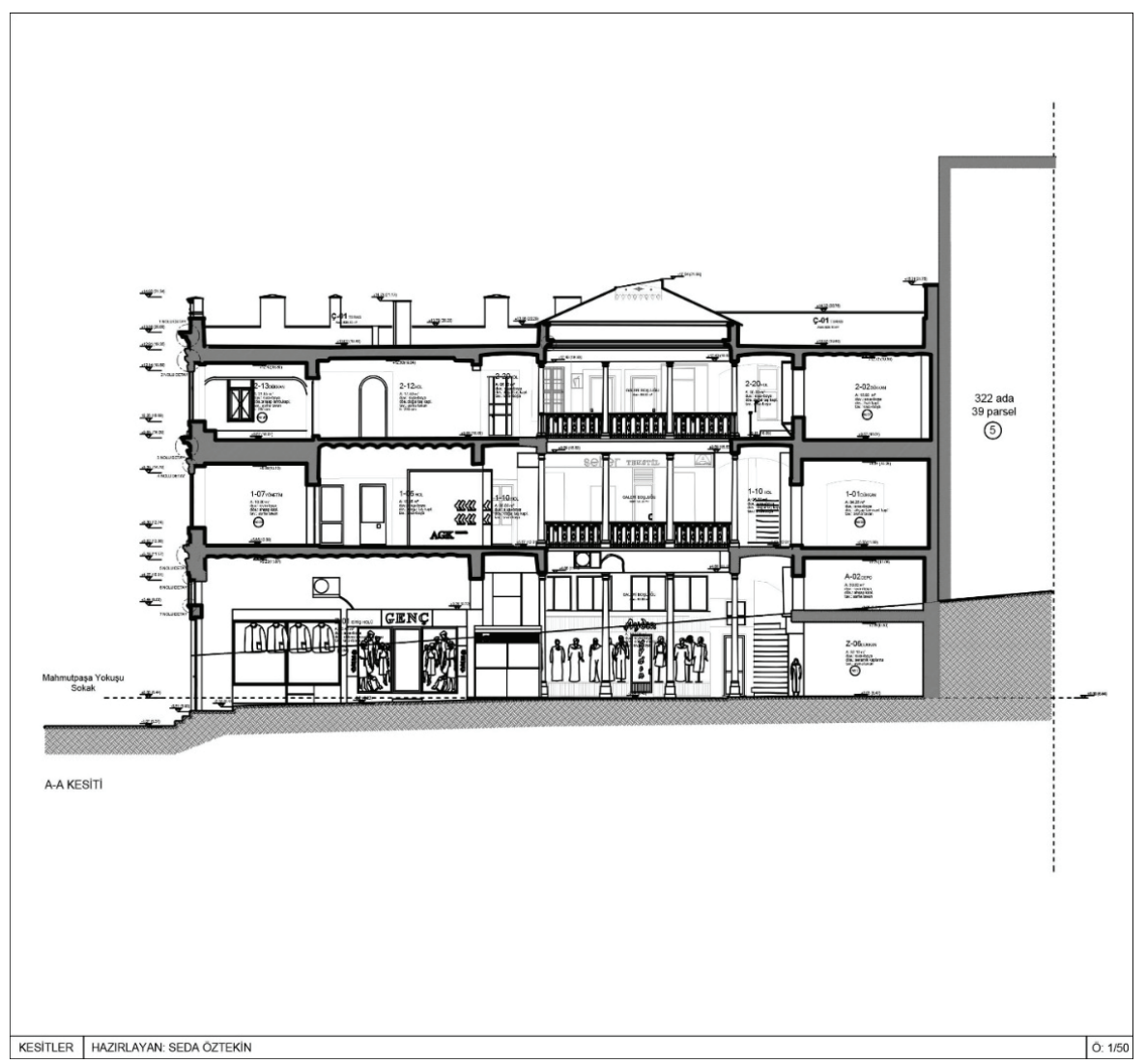

Şekil 4. Yarım Han Kesiti (Öztekin, 2016).

\subsection{Yarım Han'ın mevcut durumu ve belgelenmesi}

\subsubsection{Yapım sistemi}

Yapının 19. yüzyıl sonu inşa edilmiş olması, bu yıllara ilişkin kâgir yapım tekniklerine ve malzeme özelliklerine sahip olduğunu göstermektedir. 'Demirin taşıyıcı malzeme olarak yapım tekniği içinde yer alması, döküm prosesinin 18. yüzyıl sonundaki gelişmesinin ardından döşemelerde ahşap kirişin yerine kullanımının denenmesiyle başladı. 19. yüzyıl başında araları tuğlalarla örülü putrellerden oluşan döşeme 
tasarımları yapıldı. Rutin kullanım için ise yüzyılın ikinci çeyreğini beklemek gerekti. Çimento ve demir, görüldüğü gibi, 19. yüzyılın ortalarına kadar ayrı ayrı ve farklı teknikler ve tasarımlar içinde kullanıld1. Bu iki malzemenin birlikte 'ciment arme / demir donatılı çimento’ olarak kullanımı 19. yüzyıl ortasında başlayabildi. Esasında bir Fransız ve İngiliz buluşu olarak gelişen bu yapım tekniğinin başlangıcındaki evrimin tamamen dışında olan Osmanlı İmparatorluğu'nda kullanımı, doğrusu önemli bir gecikme olmaksızın 19. yüzyılın son çeyreğinde başladı. Çimento ve beton ise, bağlayıcı malzeme olarak geleneksel horasan harcının kullanıldığı Osmanlı mimarisinde 19.Yüzyıl ortalarından başlayarak özellikle sosyal ve ekonomik yapısı gelişip değişmekte olan ve yeniliklere açık duran liman kentlerindeki yapımlarda çeşitli bileşimler içinde kullanılmaya başlandı.' 5 Yarım Han, yığma yapım tekniğinde, avlulu, üzeri cam örtülü ve galerili olup, bu galeri boşluğunu çevreleyen holler ile tüm dükkân/depo olarak kullanılan alanlarda volta döşeme uygulaması görülmektedir (Şekil 5, Şekil 6, Şekil 7). Galeri boşluğunu taşıyan demir sütunlar, endüstri devrimi sonrası dökme demir uygulamalarına örnek olmaktadırlar. Çatıya ulaşıldığında, bu galeri boşluğu üstü özgün aydınlık doğraması ile son bulmaktadir.

5 BATUR, A. Geç Osmanlı Mimarlığında Betonarme Yapım Tekniği. İstanbul. 


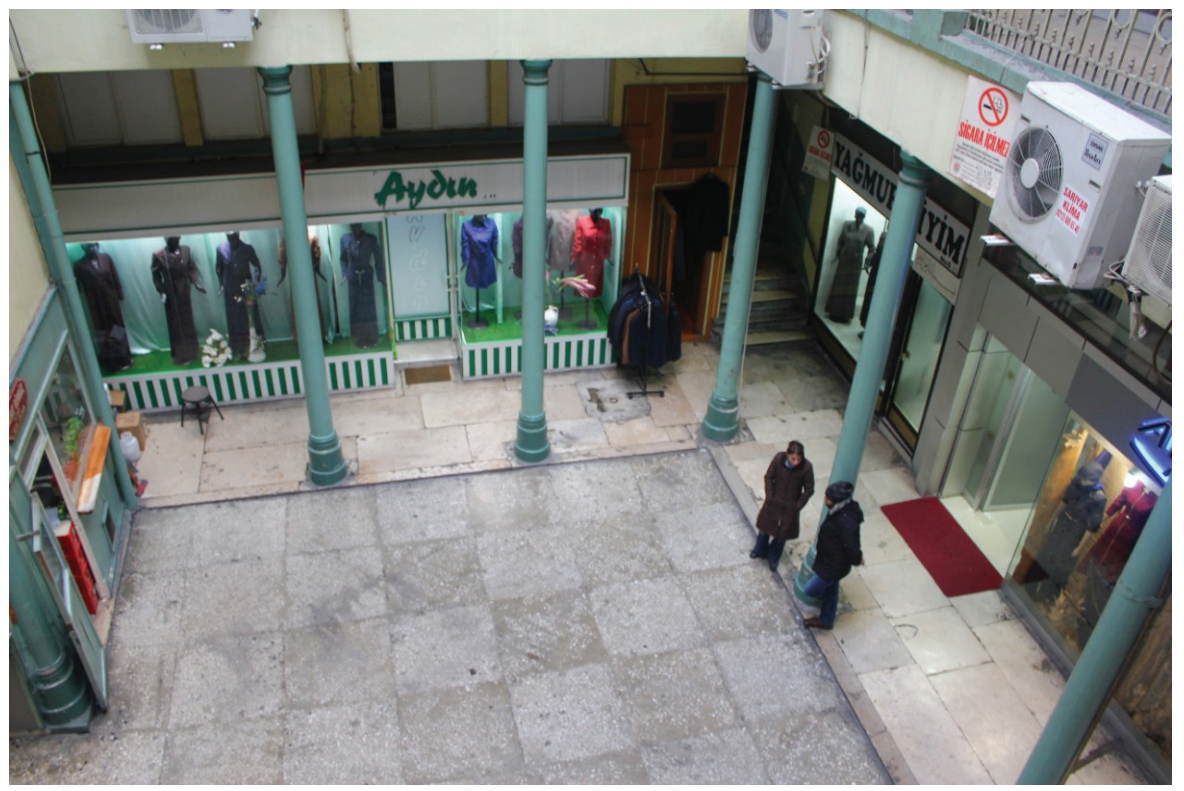

Şekil 5. Yarım Han Avluya Bakış (Öztekin,2016)

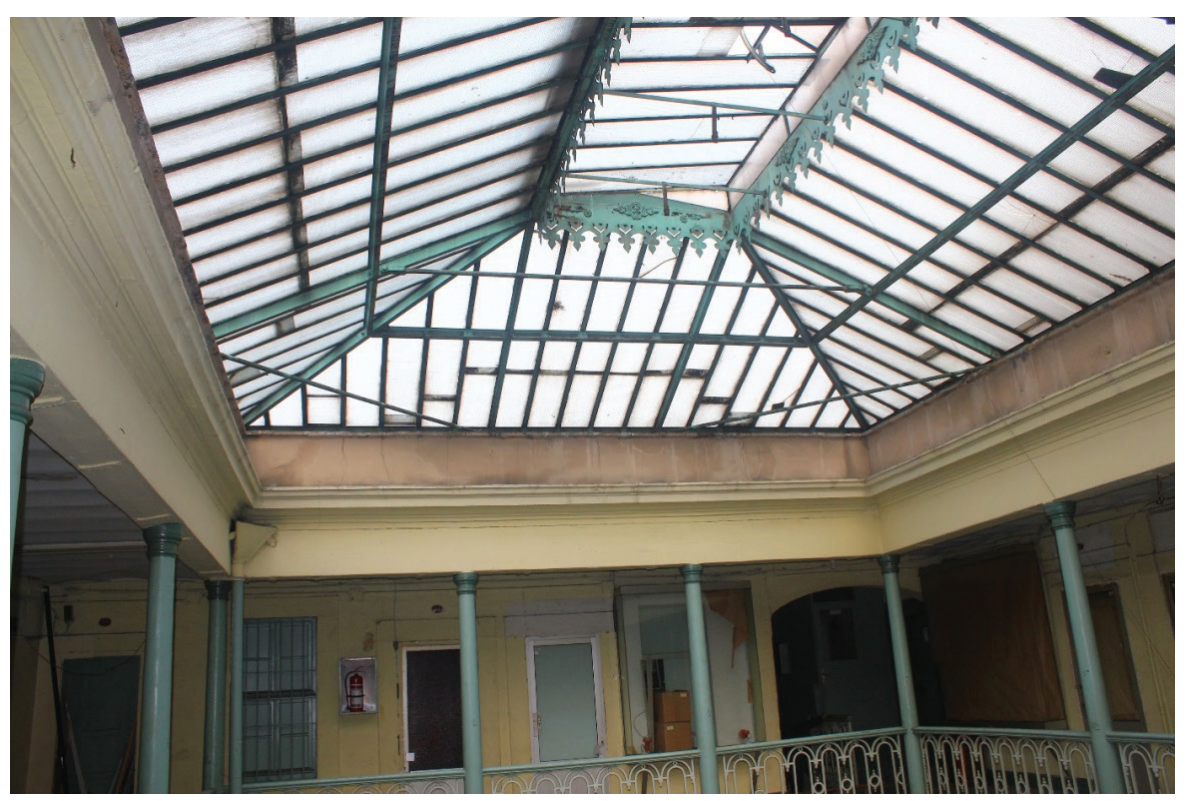

Şekil 6. Yarım Han Işıklık’a Bakış (Öztekin,2016) 


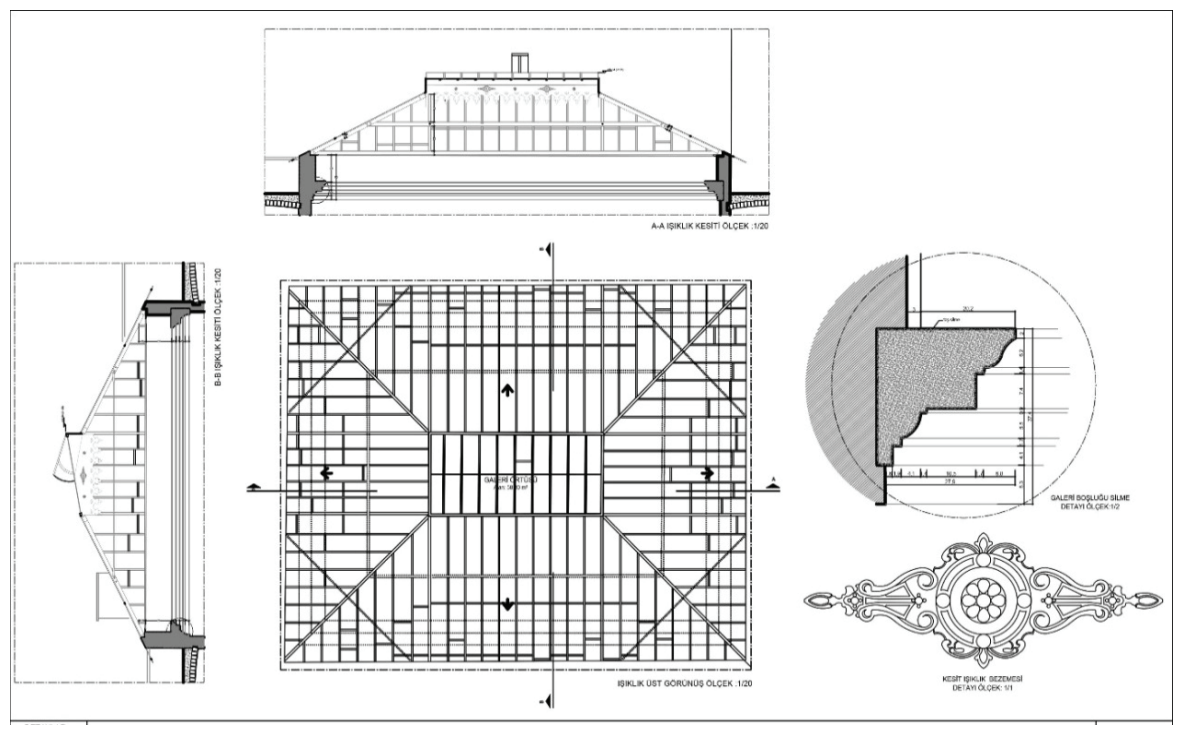

Şekil 7. Yarım Han Işıklık Çizimi (Öztekin, 2016).

\subsubsection{Plan özellikleri}

Batılılaşmanın etkisiyle görülmeye başlanan Avrupa mimarisinin örneklerinden biri olan bezemeli ön cephe, eklektik üslup özelliklerini taşımaktadır. Girişin yapıldığ 1 kotta, yarım daire kemerli açıklıklardan biri han girişi, diğeri sokaktan kullanılan dükkân girişini tanımlamaktadır. Bu kemerler taş söveler ile geçilmiştir. Kemer açıklığı içerisinde metal süslemeler yer alır. Özgün giriş kapısı günümüze kadar korunmuştur. Mahmutpaşa Yokuşu Sokağı'ndan çift kanatlı demir kapı ile hana girilerek, bir koridordan geçilip iç avluya ulaşılır. 12 adet $26 \mathrm{~cm}$ çapındaki demir sütunun taşıdığ 1 galeri boşluğu aksında yer alan bölümde dökme mozaik kaplama kullanılmaktadır. Bu alan dışında kalan avlu döşeme malzemesi doğal taş kaplamadır. Bu avludan girişi yapılan toplam 6 dükkân yer alır. Bu dükkânların genelinde görülen biz özellik özgün plan şemasının bozulması ve bu dükkânları ayıran duvarlar arasından açılan geçiş boşluklarıdır. Zemin katta dükkânlar ile 
ilgili bir diğer durum da, vitrinlerin yapılması sırasında daha fazla alan kullanabilmek için taşıyıcı niteliği olan duvarların kaldırılmasıdır.

Balansmanlı özgün taş merdiven ile birinci kata ulaşım sağlanır. Birinci kata çıkıldığında, $22 \mathrm{~cm}$ çapındaki 12 adet demir sütunun taş1dığ1 ve özgün korkuluklarla çevrelenmiş galeri boşluğu bulunur. Dükkânlar yığma tuğla duvar sisteminde olup, galeri boşluğu çevresindeki alanda ve dükkânlara giriş imkanı sağlayan hollerin tavanlarında volta döşeme açıkça görülmektedir. Bu katta da, zemin katta olduğu gibi bir müdahale biçimi olarak, özgün plan şemasındaki iki dükkân arasındaki bölücü nitelikteki taşıyıcı duvarlarda geçiş boşlukları açılmış, hacimler büyütülmüştür. $\mathrm{Bu}$ durumun yapının taşıyıcı sistemine zarar verdiği düşünülmektedir. Yine mermer basamaklı merdiven ile ulaş1lan ikinci katta, depo olarak kullanılan odalar görülmektedir. Direkt olarak sokak ile bağlantısı bulunmayan bu katta satış işlevi görülmemektedir. Kullanıcıların az olduğu bu katın en önemli özelliği, galeri boşluğuna açılan taş söveli kapı ve pencere yerlerinin özgün olmasıdır. Genel anlamda en çok korunan kat niteliğindedir.

\subsubsection{Cephe özellikleri}

Mahmutpaşa Yokuşu Sokağı cephesinde, katlar arasındaki geçiş cepheye profilli taş silmeler ile taşınmıştır. 1.katta dikdörtgen formda iki pencere üzerinde basık kemer formunda alınlık görülmektedir. Pencerelerin her iki yanında dikine yer almış olan söveler, başlıklar yardımıyla taş alınlıkları taşır. Niteliksiz alüminyum pencereler dikkat çeker. Bu iki pencere arasında istiridye motifli çeyrek küre kavsaralı niş içinde yine bitkisel motif ve yapraklar görülmektedir. İkinci katta, yine dikdörtgen formda iki pencerenin aynı aksta devam ettiği ve üçgen alınlık ile sonlandığı görülmektedir (Şekil 8). 


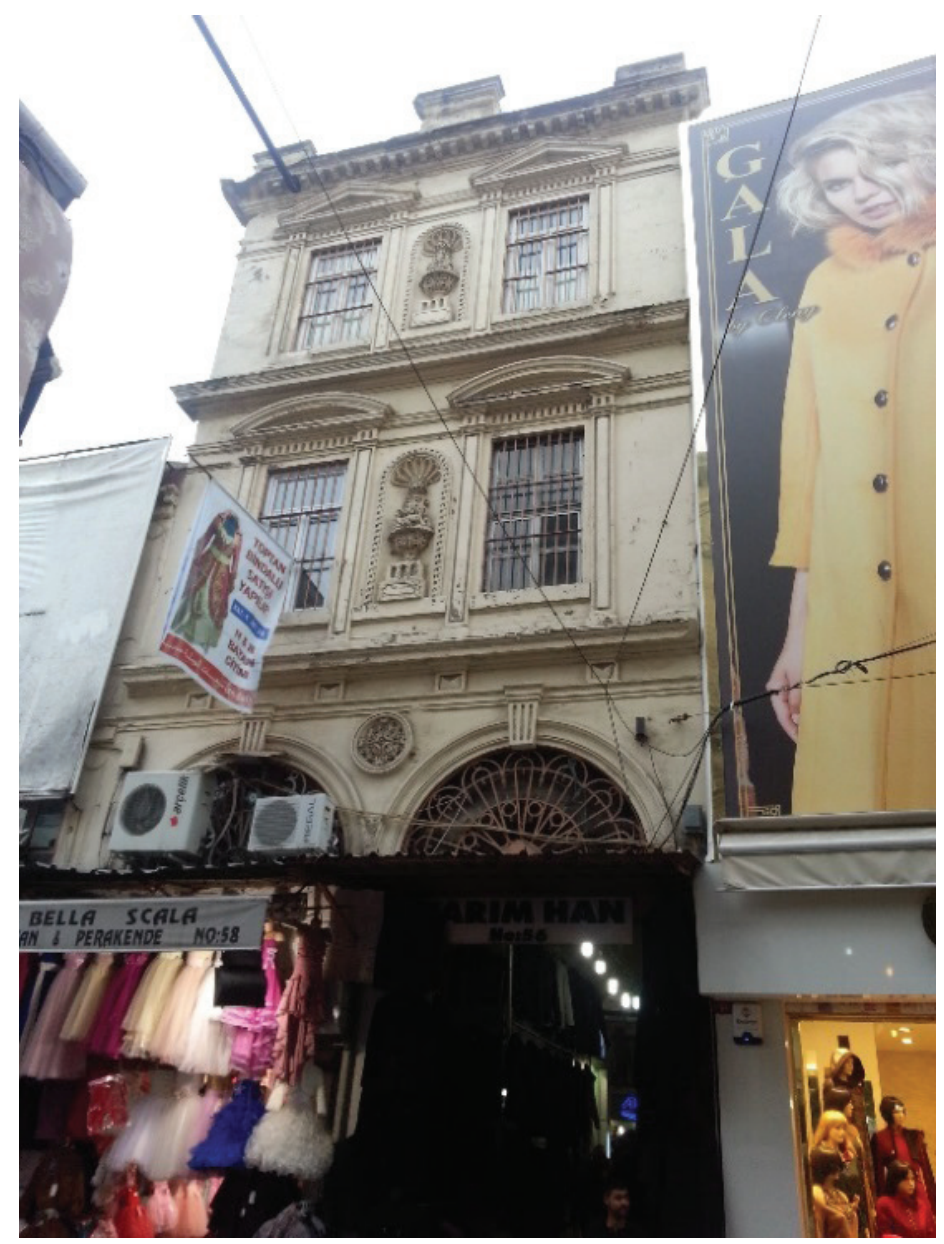

Şekil 8. Mahmutpaşa Yokuşu Sokak Cephesi (Öztekin, 2016).

Bezciler Sokağı üzerinden 30 kapı numaralı kısımdan Yarım Han'a giriş yapılır. Ön cepheye nazaran oldukça sade olan bu cephede 4 dükkân vardır. Bu dükkânlara ait reklam panoları, niteliksiz alüminyum doğramalar cephe bütünlüğünü bozmaktadırlar. Özgün bir demir kapı ile bu kapı üzerinde yer alan yarım daire formundaki taş kemer arasından profilli silme görülür. Kilit taşı üzerinde de bir taş silme dikkat çeker. Birinci kat ile ikinci katı birbirinden bir taş kat silmesi ayırır. Bu katta toplam 11 pencere boşluğu yer almaktadır. birinci katta 
olduğu gibi, bu katta da pencereler ikişerli olarak taş söve kullanılarak sınırlandırılmıştır. Cephenin sağındaki iki pencere modülü bozulmuş, cepheden çıkan alüminyum doğramalar ile kapatılmıştır. 3 özgün pencere dışında, diğer pencereler niteliksizdir. Cephe profilli bir taş saçak silmesi ile sonlanır (Şekil 9).

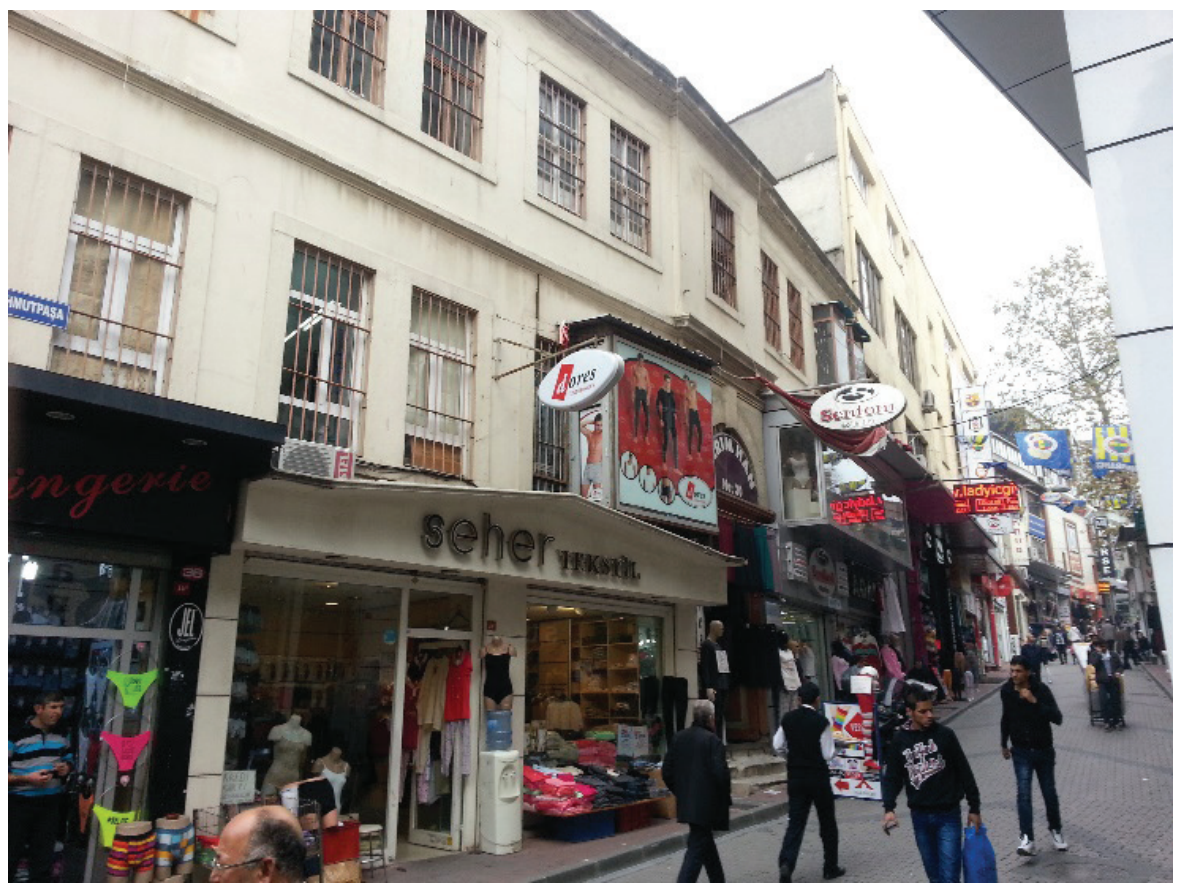

Şekil 9. Bezciler Sokak Cephesi (Öztekin, 2016).

\subsection{Yapıdaki hasar tespitleri}

Yarem Han (Yarım Han) özgün plan şeması ve kullanılan malzeme açısından incelendiğinde mevcut durumuna ilişkin olarak nitelikli bir onarım geçirdiği söylenemez. Ticaret işlevi ve sergileme ihtiyacı nedeniyle özellikle zemin katta olmak üzere niteliksiz vitrin uygulamalarına gidilmiştir. Zemin kattaki taşıyıcı nitelikli duvarlara verilen zarar ile yapının strüktürel açıdan iyi durumda olduğu söylenemez. Cephe özellikleri bakımından da bakıldığında doğal etkenlere bağlı yıpranma ve kayıplar dikkat çeker. 


\subsubsection{Yanlış kullanıma bağlı bozulmalar ve niteliksiz ekler}

1962'den bu yana özel mülkiyete geçmiş olan Yarım Han yapısı, inşa edildiği zamandan bu yana ticari işlevini sürdürmektedir. Kullanıcı ihtiyaçları bazı ek yükler getirmiş ve bu değişiklikler özgün kullanımın bozulmasına neden olmuştur. $\mathrm{Bu}$ yeni işlevle yapının hem zemin katında hem de birinci katında ekler yapılmış ve kullanıma bağlı sorunlar başlamıştır. Mahmutpaşa Cephesi yönüne bakan iki 1şıklık zemin katta kapatılmış ve asma kata ulaşımı sağlayan merdivenler yerleştirilmiştir. Ayrıca, üst katlarda bulunan ıslak hacim mekânı bu katta kapatılarak dükkâna katılmıştır. Bu durum tesisat problemine yol açmaktadir.

Birinci ve ikinci katlarda plan şeması özgün halini korumaktadır. Kap1 ve pencerelerin muhdes malzeme ile yeniden yapılması ve cam vitrinlerin oluşturulmuş olması dikkat çeker. .

Çatı katında, özgün durumu marsilya kiremitli kırma çatı zaman içinde kaldırılmış ve teras çatı olarak kullanılmaya başlanmıştır. Kullanım Büyük Yıldız Han’dan sağlanmaktadır.

\subsubsection{Cephede görülen bozulmalar}

Mahmutpaşa Yokuşu'na bakan ön cephede yer alan özgün demir giriş kapısında niteliksiz yüzey boyası ve bezemelerde korozyon gibi bozulmalar dikkat çekmektedir. Cephelerde genel olarak yüzey kirlenmesi mevcuttur. Taş sövelerde ve silmelerde ve pencere çevrelerinde yoğun olarak kirlenme ile kararmalar oluşmuştur. Pencerelerin taş sövelerinde ayrışma, kırılma ve çatlaklar görülmektedir. Parapetlerde yoğun kirlenme ve yüzeysel aşınmaların yanı sıra parça kayıpları vardır. Bu yüzeyin bir kısmında nitelikli olmayan bir sıva ile onarım yapıldığg görülmektedir. Saçak silmesinde ve kat silmelerinde kırık k1sımlar ve kopmalar görünür iken, yosun oluşumunun başladığını söylemek mümkündür. Niteliksiz pvc ve alüminyum malzemenin kullanıldığı doğramalar ve demir parmaklıklar özgün değildir. 
Bezciler Sokak cephesinden yapılan yan giriş görülen bozulmalar ön cephedeki kapı ile yanıdır. Niteliksiz dış cephe boyasının kullanılmasıyla taş sövelerin yüzeyden ayırt edilmesi zorlaşmıştır. $\mathrm{Bu}$ cephede, geleneksel çarşı dokusuna aykırı dükkân girişleri, kepenk sistemleri ve reklam levhaları gibi niteliksiz onarımlar dikkat çekmektedir. Aynı şekilde, hanın içinden de kullanılan bazı dükkânların cepheye yansıttıkları niteliksiz vitrin düzenleri görülmektedir. Sıva çatlaklarının görüldüğü bu cephede, saçak silmesinde ve kat silmesinde kirlenme görülür. Özgün olmayan demir parmaklıkların oluşturduğu pas lekesi duvar yüzeyinde kirlilik oluşturmuştur.

\section{Yarım Han Yapısının Tarihine İlişkin Belgeler}

Yarım Han (Yarem Han), dış cephe özellikleri bakımından özgünlügünü büyük ölçüde koruyarak günümüze ulaşmış bir yapı olmasına rağmen, kullanıcılarının ve işlevinin değişmesi yapıyı çeşitli oranlarda etkilemiş ve iç mekânlar da oldukça fazla değişime uğramıştır. $\mathrm{Bu}$ nedenle yapının tasarımına dair birçok restitüsyon sorunu mevcuttur. Restitüsyon önerisi hazırlanırken, yapıya ait eski çizim bulunamamış, arşiv araştırmaları içerisinde Encümen Arşivi’nde eski bir fotoğrafa ulaşılmıştır. Bu araştırma kapsamında pek çok tez ve diğer yazılı kaynakların yanı sıra, eski haritalardan yararlanılmıştır. Arşiv araştırmalarına ek olarak, han yapısının dönem özelliklerini taşıyan benzer örnekler incelenmiştir. Ticaret işlevi gerekçesiyle, Ticaret Yıllıkları incelenmiştir.

\subsection{Eski haritalar}

Yarım Han (Yarem Han) ve çevresinin tarihine 1şık tutabilmesi için eski haritalar incelenmiştir. Kronolojik bir sırayla incelendiğinde, 1874 tarihli Ayverdi haritasında görülmemektedir. Yarım Han yapısının görüldüğü ilk harita 1900lerin başına tarihlenen W. Marklin \& Co. Damgalı bölge haritasıdır. Haritada yapının komşuları olan Yaldız 
Han (Büyük) ve Tahta Han ile olan ilişkisi görülmekte olup, Rue Mahmoud Pacha Yokouchou (günümüz Mahmut Paşa Yokuşu Sokak) ile Rue Mahmoud Pacha (Djamissi) (günümüz Bezciler Sokak) üzerinden yapılan girişleri görülmektedir. Cam 1şıklık dikdörtgen formda işlenmiştir. (Şekil 10). Bu haritadan biraz daha detaylı olarak Yarım Han yapısının görüldüğü, diğer yapılara ait parselizasyonun ve yapı girişlerinin tanımlandığı harita 1905 tarihli Goad Haritasıdır.(Şekil 11). Ancak, sonraki yıllarda hazırlanan I. Dünya Savaşı öncesi İstanbul'una ait 1913-1914 tarihleri arasında tamamlanan Alman Mavileri'nde ve 1918 yılı Necib Bey haritasında Yarım Han görülmemektedir. Yap1nın en detaylı biçimde görüldüğü harita ise 1940 tarihli Pervititch sigorta haritasıdır (Şekil 12). Yapı Mahmutpaşa Yokuşu Sokağı tarafından üç katlı, Bezciler Sokak tarafından iki katlı olarak gösterilmiştir. Mahmutpaşa Yokuşu Sokağı'ndan 56 no.'lu tonozlu bir geçiş ile avluya ulaşıldığı, aynı şekilde Bezciler Sokak tarafından 30 no.'lu, yine tonozlu bir geçişle aynı avluya ulaştığı gösterilmiştir. Avluda yer alan ve günümüze kadar korunmuş olan 12 adet sütun ve bu sütunların taş1dığı cam 1şıklık görülmektedir. Mekân bölümlemeleri yapılırken özellikle bu haritadan yararlanılmıştır. Aynı şekilde silüetin oluşturulmasında kat yükseklikleri dikkate alınmıştır. 


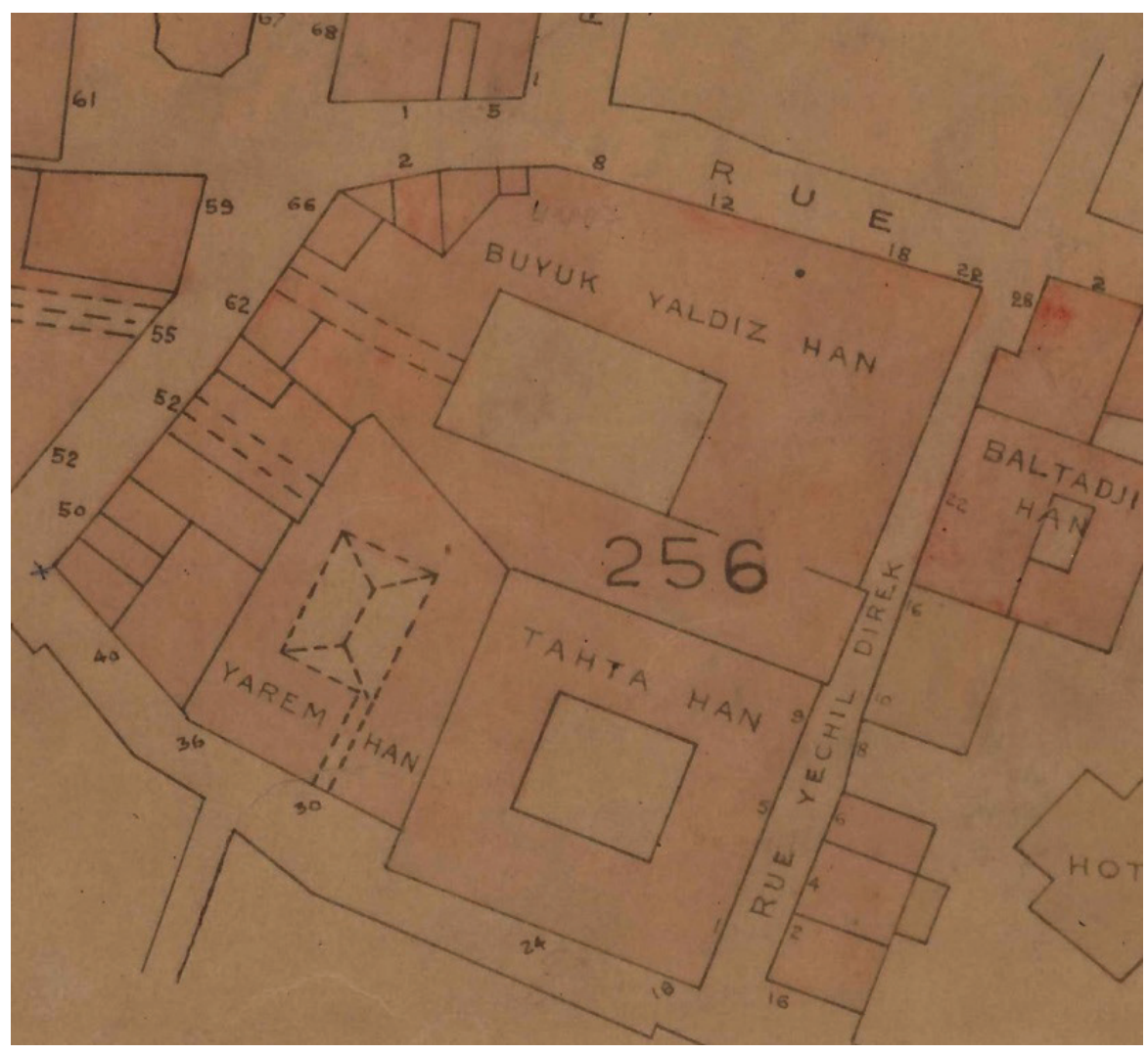

Şekil 10. W. Marklin \& Co. Damgalı bölge haritası detayı. 


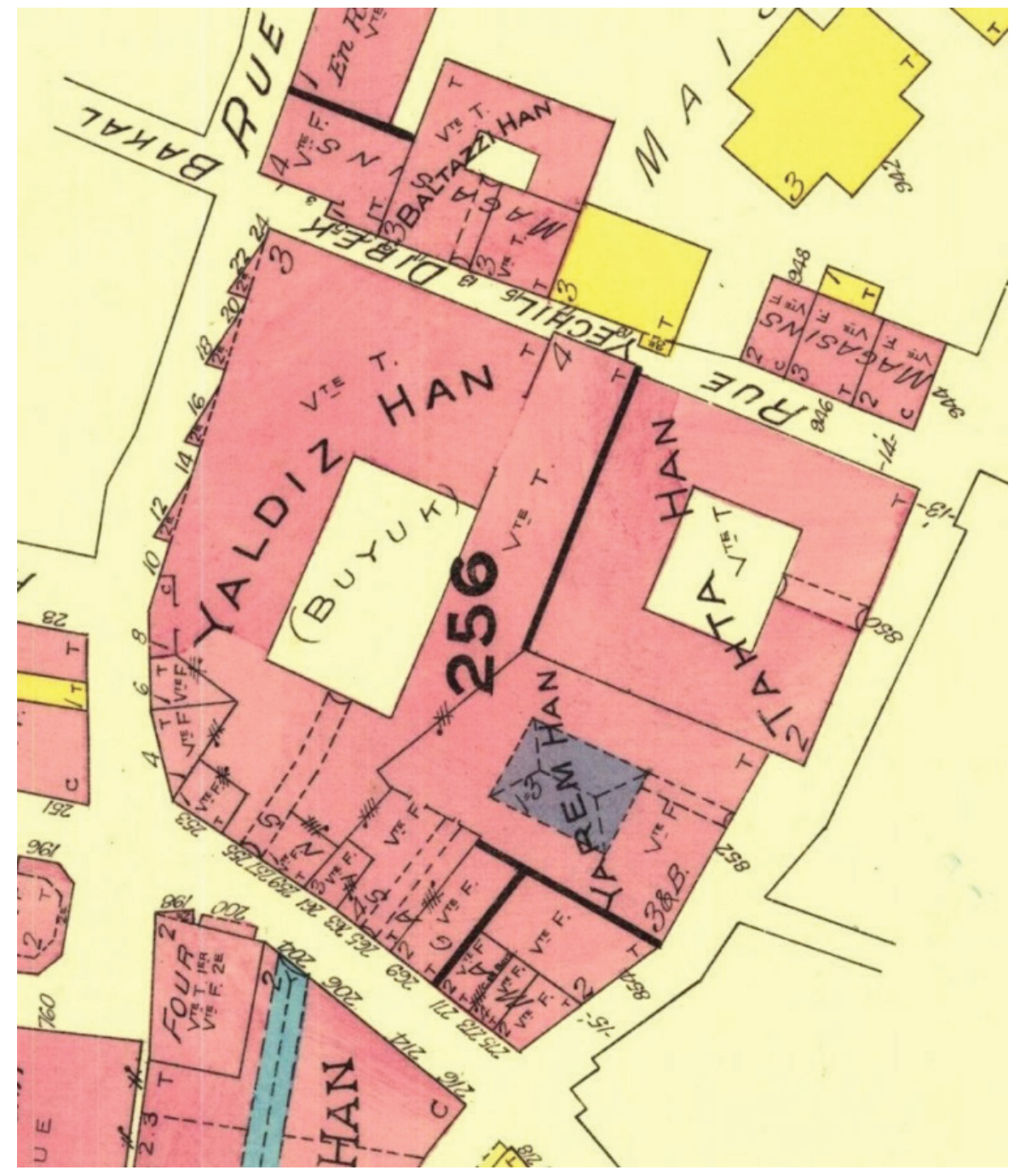

Şekil 11. 1905 tarihli Goad haritası detayı. 


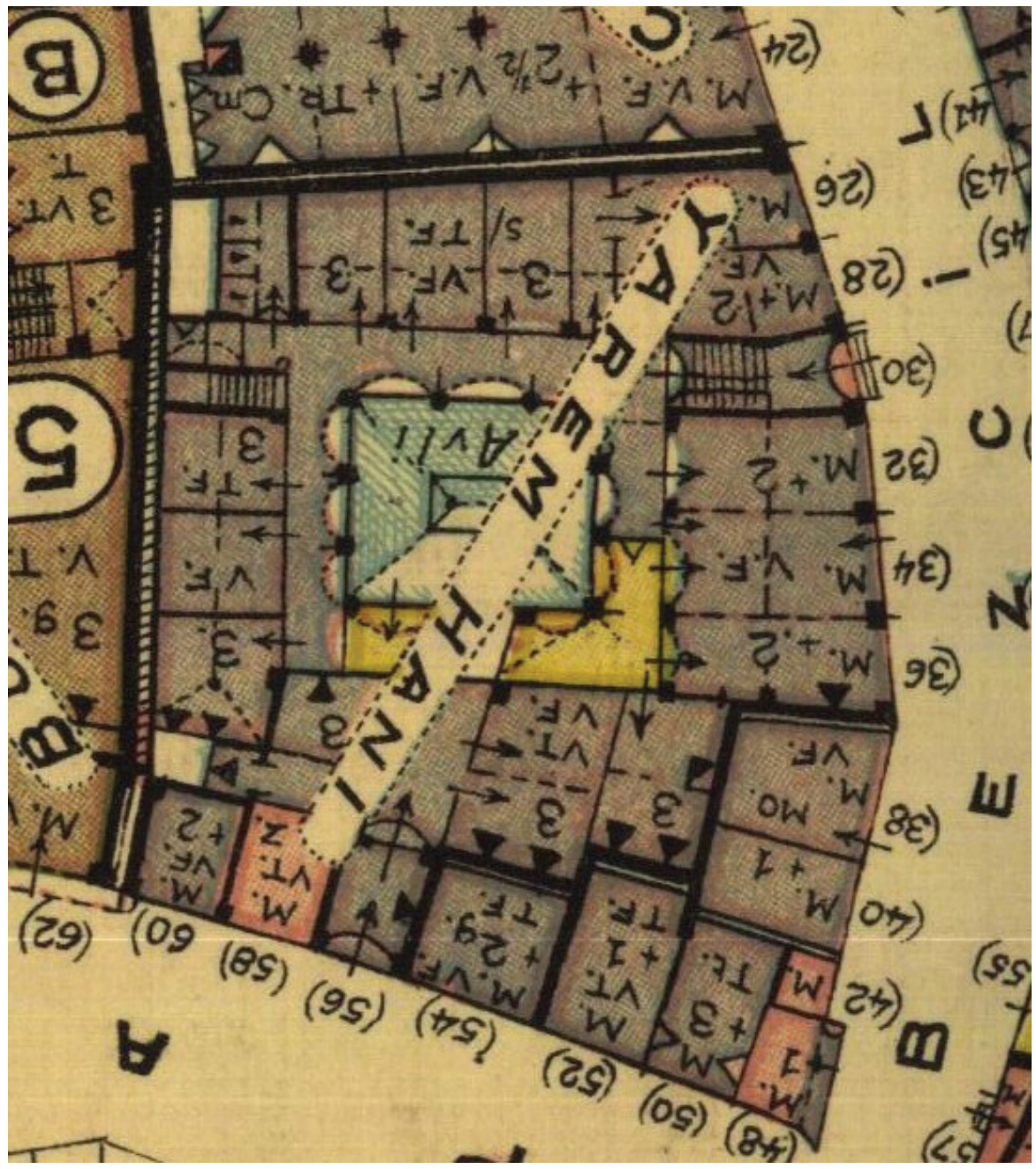

Şekil 12. 1940 tarihli 63 numaralı Pervititch sigorta haritası detay1.

\subsection{Eski fotoğraflar}

Fatih Belediyesi Arşivi, Arkeoloji Müzesi Encümen Arşivi'nde yap1lan araştırmalar sonucunda 1970'lerden öncesine ait fotoğraflara ulaşılmıştır. Yalnız, yapının dışından çekilmiş olan bu fotoğraflar iç avlusuna ya da dükkânlara dair bir bilgi taşımamaktadır. 
Yapının çatı restitüsyonu önerisinin hazırlanmasında, özellikle 18.09.1940 y1lına ait, Encümen Arşivinden alınan bir fotoğraf (Şekil 13) ile 1966 yılına ait hava fotoğrafı oldukça yarar sağlamıştır (Şekil 14). Yarım Han yapısı Tarihi Yarımada üzerindeki Hanlar Bölgesindeki konumu gereği, bölge olarak araştırılmış, geleneksel çarşı dokusuna ait eski fotoğraflardan da yararlanılmıștır. Bu fotoğraflara, Fatih Belediyesi Arşivinde yapılan kapsamları araştırma sonucu ulaşılmıştır (Şekil 15, Şekil 16, Şekil 17, Şekil 18).

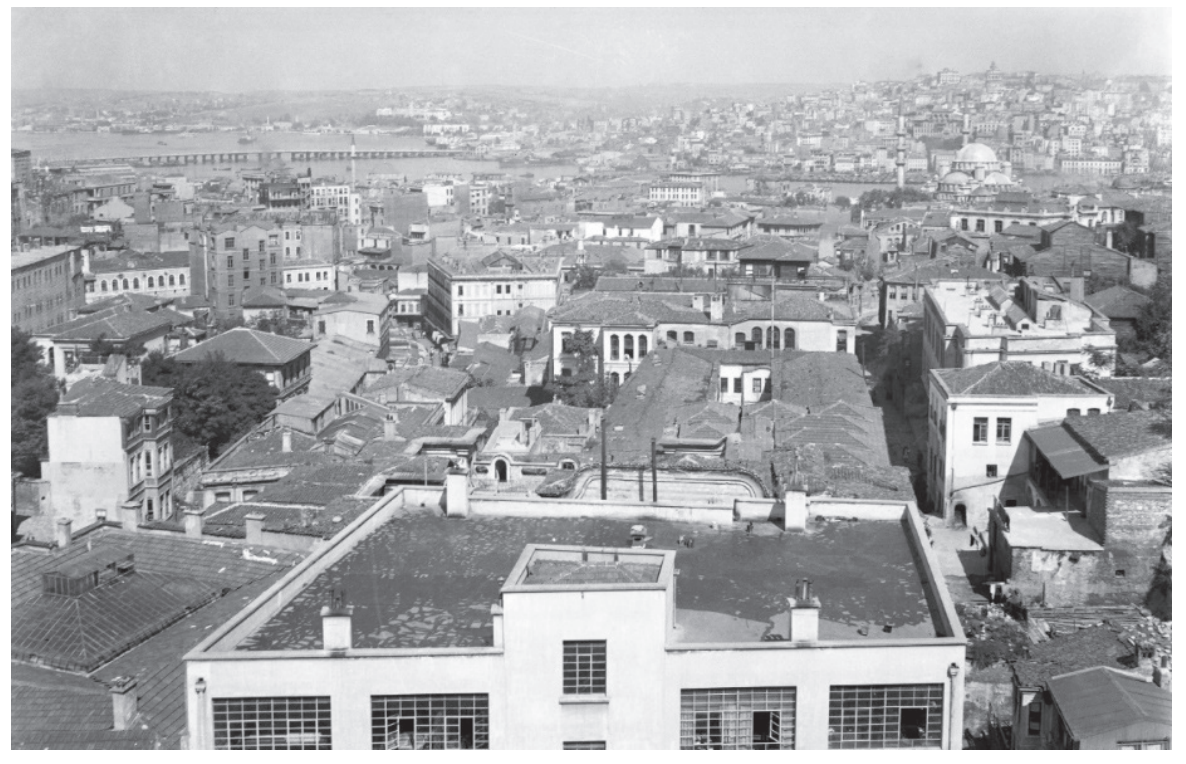

Şekil 13. 1940 yılına ait Yarım Han çatı fotoğrafı (Encümen Arşivi). 


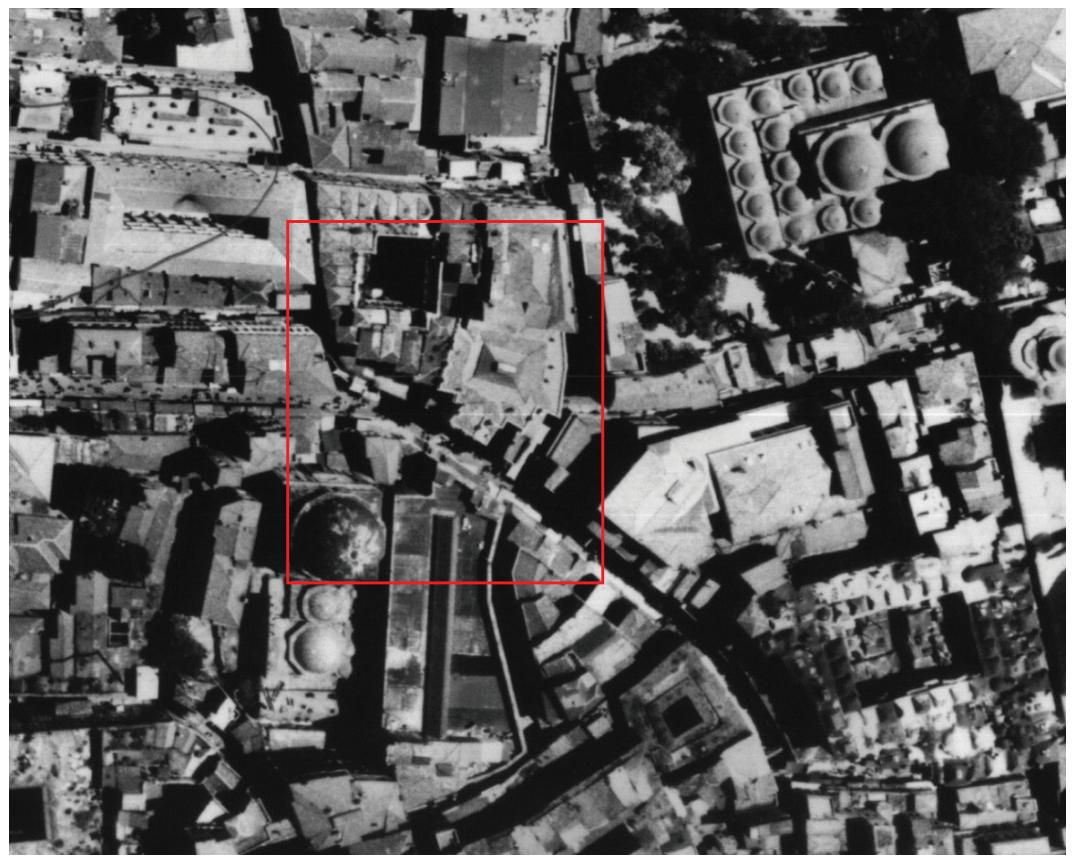

Şekil 14. 1966 tarihli hava fotoğrafı detayı.

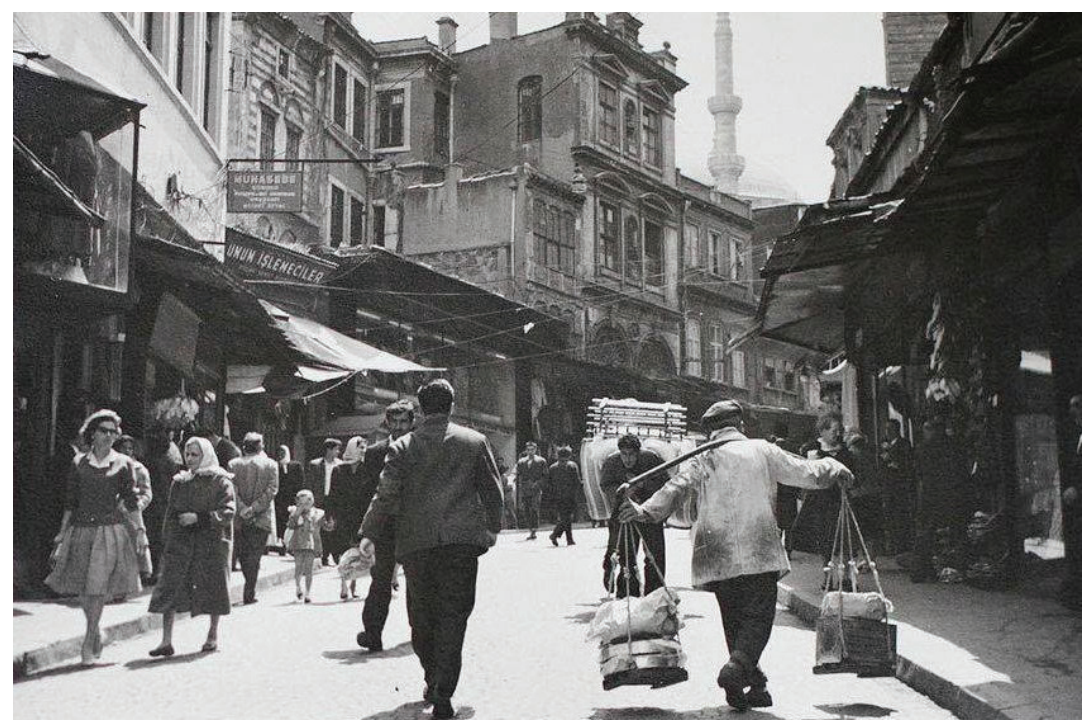

Şekil 15.1970liyıllaraaitMahmutpaşa YokuşuSokak.(FatihBelediyesiArşivi). 


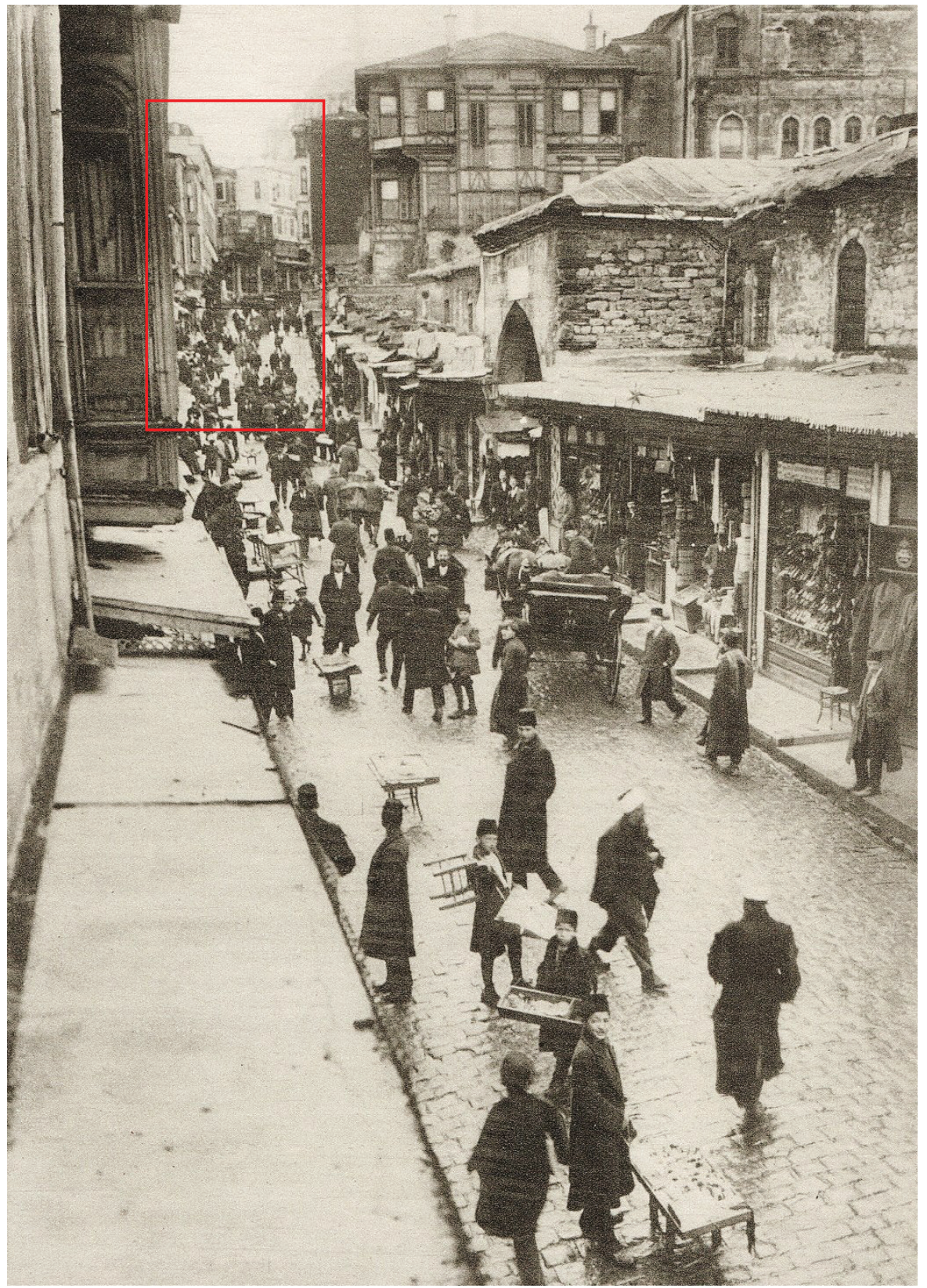

Şekil 16. 1915 tarihli Mahmutpaşa Yokuşu Sokak (Kürkçü Han'a bakış) (Fatih Belediyesi Arşivi). 


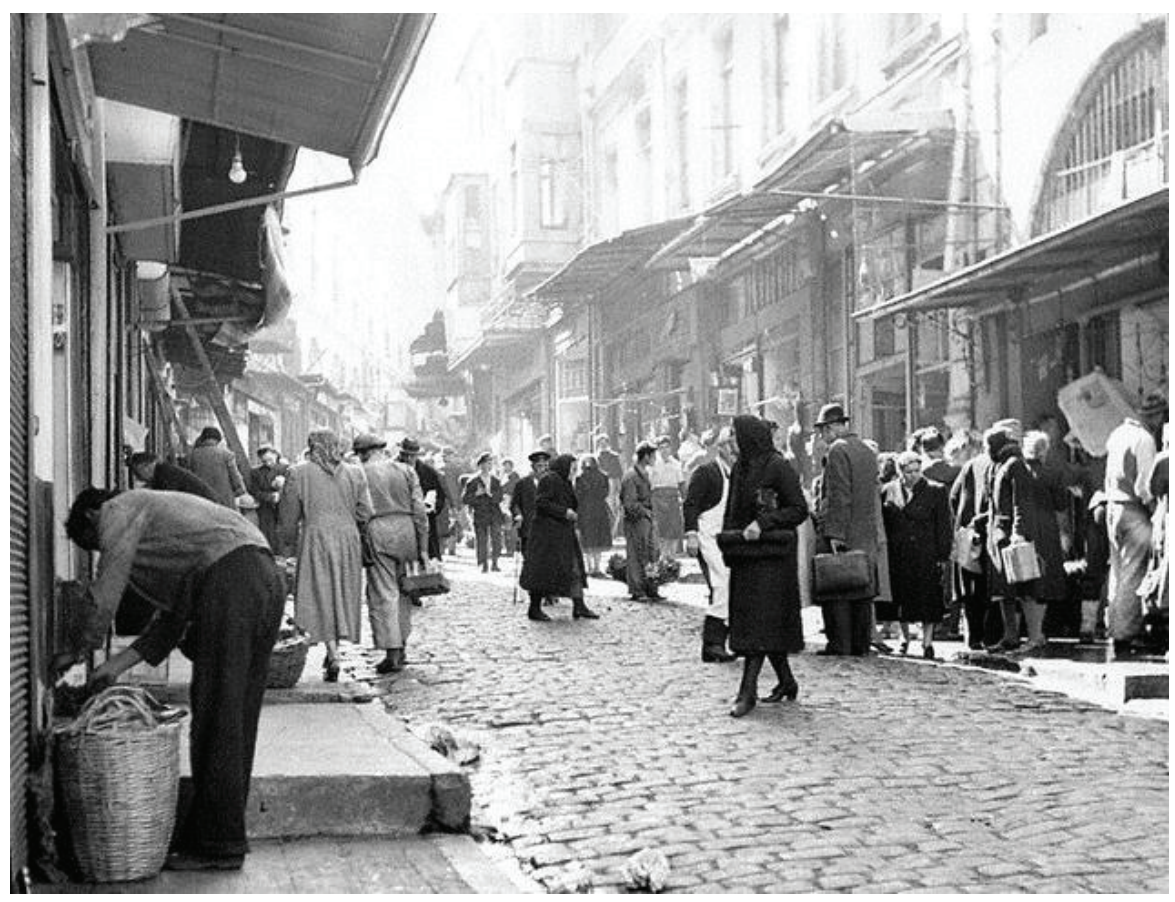

Şekil 17. 1970li yıllara ait Mahmutpaşa Yokuşu Sokak. (Fatih Belediyesi Arşivi). 


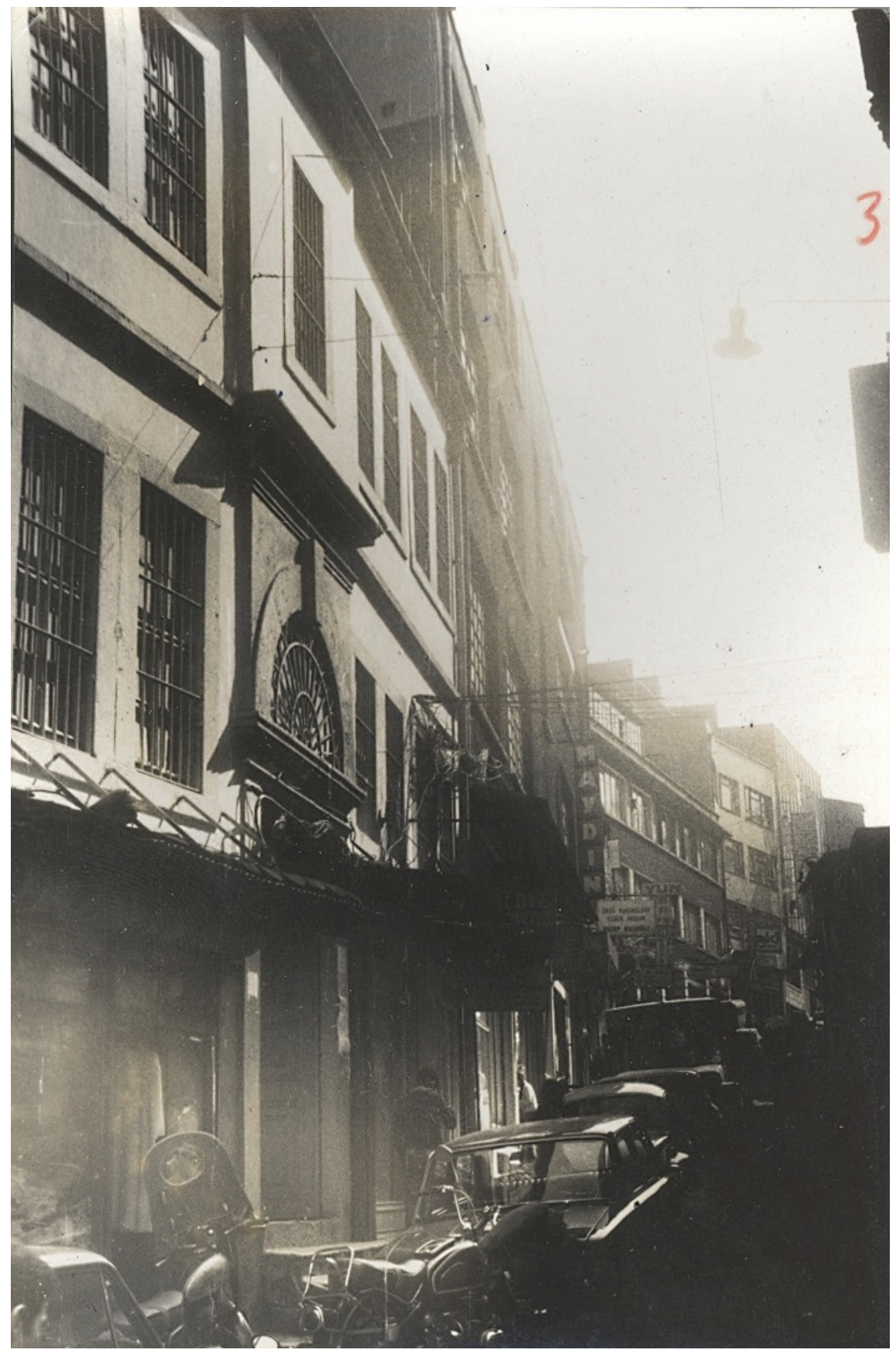

Şekil 18. 1974 yılına ait Yarım Han yan cephe. (Fatih Belediyesi Arşivi). 


\section{3 Şark ticaret yıllıkları}

Ticari işlevi gerekçesiyle, kullanıcı özelliklerinin belirlenmesi bakımından 1880- 1883 yılları arasındaki Indicateur Ottoman Illustre, 1887-1888 yılları arasındaki Indicateur Oriental, 1889- 1930 yılları arasındaki Annuaire Oriental ve 1931- 1945 yılları arasındaki Şark Yıllıkları incelenmiştir.

İlk olarak, 1889-90 Annuaire Oriental yıllığında Yarem Han(Djedid) olarak listelendiği görülmektedir. (Tablo 1). Ağırlıklı olarak tüccar- komisyoncu ve terzi meslek grubu karşımıza çıkmışken, günümüzde de kahvehane işlevinin yapıldığı bölümde olduğu düşünülen 14 nolu Boghossian (Miguirditch), kahve mekânının varlığı dikkat çekmektedir. Toplamda 17 ayrı kullanıcı belirlenmiştir. 1891 Annuaire Oriental yıllığında, Djedid Yarem Han olarak kayıt altına geçmiştir. 14 kullanıcının olduğu listede, tüccar- komisyoncu ve terzi meslek grubunun ağırlıklı olarak devam ettiği görülmektedir (Tablo 2) .

Tablo 1.1889-90 Annuaire Oriental

\begin{tabular}{|l|l|}
\hline No 2. Sidefdjian (Minasse), tüccar. & 20. Ipekian (Stepan), komisyoncu. \\
\hline 4. Tavoukdjioglou (Dimitri), tüccar. & 22. Sakayan (Gabriel), terzi. \\
\hline 5. Agopian et Abdullahian, terzi. & 26. Maraschlian (Andon), komisyoncu. \\
\hline 6,7,8. Lévy (David), halı. & 27,28. Sarafian (H.), tüccar. \\
\hline $\begin{array}{l}\text { 9.Sayim Dahr (Ibrahim), tüccar- komis- } \\
\text { yoncu }\end{array}$ & 29. Enomotarche (J.), avukat. \\
\hline 11. Donchian (Dicran), komisyoncu. & 31. Luling (Théodore), depo. \\
\hline 12. Arapian (Serkis K.), komisyoncu. & 36. Kerekdjian (Dicran), komisyoncu. \\
\hline 14. Boghossian (Miguirditch), kahve. & 38. Kéchichian (H.), kurumsal başkan. \\
\hline 16. Anastassiadés (Paul), terzi. & \\
\hline Odabaş1: Tzacouropoulos (Costis) et Hussein Effendi. \\
\hline
\end{tabular}


Tablo 2. 1891 Annuaire Oriental

\begin{tabular}{|l|l|}
\hline No 2,3. Zenguianli (Aghadjan), halı. & 12. Arapian (Serkis K.), komisyoncu. \\
\hline 4. Temurian (Setrak), halı. & 14. Kazadjian (Dicran), halı. \\
\hline 5. Kazandjian (Yervant), halı. & 16. Anastassiadés (Paul), terzi. \\
\hline $\begin{array}{l}\text { 6,7,8. Lévy (David), halı. } \\
\begin{array}{l}\text { 9.Sayim Dahr (Ibrahim), tüccar- komis- } \\
\text { yoncu }\end{array}\end{array}$ & 20. Ipekian (Stepan), komisyoncu. \\
\hline $\begin{array}{l}\text { 11. Selim Kasayan (Gabriel), terzi. } \\
\text { yoncu. }\end{array}$ & Zadé Effendi, komis- \\
\hline 27,28. Serpossian Fréres, kuyumcu. & 29. Enomotarche (J.), avukat. \\
\hline Odabaş1: Tzacouropoulos (Costis) et Hussein Effendi. \\
\hline
\end{tabular}

1892-93 Annuaire Oriental yıllığında, 12 kullanıcı ve meslek grubu belirlenmiştir (Tablo 3).

1893-94 Annuaire Oriental yıllığında, daha önceki kullanıcılardan farklı olarak, nakışçı ve mizik aleti satıcısı görülmüştür. Toplam kullanıcı 14 tür (Tablo 4).

Tablo 3. 1892-93 Annuaire Oriental

\begin{tabular}{|l|l|}
\hline No 2,3. Zenguianli (Aghadjan), halı. & 12,13. Kazazian (D.), imalatç1. \\
\hline 4. Nassan (M.), komisyoncu. & 15,16. Ezépos (B.), halı. \\
\hline 5. Kazandjian (Yervant), halı. & 20. Ipekian (Stepan), komisyoncu. \\
\hline 6,7,8. Lévy (David), halı. & 22. Sakayan (Gabriel), terzi. \\
\hline $\begin{array}{l}\text { 9.Sayim Dahr (Ibrahim), tüccar- komis- } \\
\text { yoncu }\end{array}$ & 26. Temurian (Setrak),halı. \\
\hline $\begin{array}{l}\text { 11. Selim Kassap Zadé Effendi, komis- } \\
\text { yoncu. }\end{array}$ & 28. Holass (P.), komisyoncu. \\
\hline Odabaşı: Tzacouropoulos (Costis) et Hussein Effendi. \\
\hline
\end{tabular}


Tablo 4. 1893-94Annuaire Oriental

\begin{tabular}{|l|l|}
\hline No 2,3. Zenguianli (Aghadjan), halı. & 19. Kazazian (Garabe), tüccar. \\
\hline 4,5. Kechichian (Kevork), imalaţ̧1. & 20. Kaisserlian (Artin), avukat. \\
\hline 6,7,8. Lévy (David), halı. & 22. Sakayan (Gabriel), terzi. \\
\hline $\begin{array}{l}\text { 9.Sayim Dahr (Ibrahim), tüccar- komis- } \\
\text { yoncu }\end{array}$ & 25. Yacar (David), oryantal nakış̧1. \\
\hline $\begin{array}{l}\text { 11. Selim Kassap Zadé Effendi, komis- } \\
\text { yoncu. }\end{array}$ & 26. Temurian (Setrak),hal1. \\
\hline 12,13. Kazazian (D.), imalatç1. & 27, 28. Holass (P.), komisyoncu. \\
\hline 15,16. Beglian (G.) Fréres, halı. & $\begin{array}{l}\text { 46. Numan (Rahabi), yerli müzik aleti } \\
\text { üreticisi. }\end{array}$ \\
\hline Odabaş1: Tzacouropoulos (Costis) et Hussein Effendi. \\
\hline
\end{tabular}

1895 Annuaire Oriental yıllığında, kullanıcı sayısında ciddi artış gözlenmiştir. 24 ayrı kullanıcının görüldügü yılda, meslek gruplarında da çeşitlilik vardır. Bijüteri ve kuyumcu gibi takılarla ilgili satıcılar bulunmaktadır (Tablo 5).

Tablo 5. 1895 Annuaire Oriental

\begin{tabular}{|l|l|}
\hline No 2,3. Zenguianli (Aghadjan), halı. & 25. Maymon (R.), oryantal nakışçı. \\
\hline 4,5. Alsidjian (M.), altın. & 28. Devrichian (N.), makaleci \\
\hline 6,7,8. Lévy (David), halı. & 32. Hadji Mohammed, ince boyama. \\
\hline $\begin{array}{l}\text { 9.Sayim Dahr (Ibrahim), tüccar- komis- } \\
\text { yoncu }\end{array}$ & 33.Allahverdian (Z.), perdeci \\
\hline $\begin{array}{l}\text { 11. Selim Kassap Zadé Effendi, komis- } \\
\text { yoncu. }\end{array}$ & 34. Bezazian (Mardik), ipek \\
\hline 12,13. Kazazian (D.), imalatç1. & 39. Mazlimian (David), bijüterici. \\
\hline 15,16. Beglian (G.) Fréres, halı. & 40.Alyanakian (H.), kuyumcu. \\
\hline $\begin{array}{l}\text { 19. Kazazian (Garabe), tüccar. } \\
\text { 20. Kaisserlian (Artin), avukat. }\end{array}$ & 41. Agopian (Missal), bijüterici. \\
\hline $\begin{array}{l}\text { 21. Halbis (Philippe), oryantel merak- } \\
\text { lis1. }\end{array}$ & 44. Yasmadjian (M.), bijüterici. \\
\hline 22. Sakayan (Gabriel), terzi. & 49. Mehmedoglou (I.), tüccar. \\
\hline 23. Azarian (Stepan), tasarımc1. & 51.Pangalos (Jean), oryantel meraklıs1. \\
\hline Odabaş1: Tzacouropoulos (Costis) et Hussein Effendi. \\
\hline
\end{tabular}


1896 Annuaire Oriental yıllığında ilk kez katlar ayrı ayrı belirtilmiştir. 3 ayrı katın da kullanımı görülmektedir. Üst kata çıkıldıkça kullanıcı sayısında azalma görülür (Tablo 6).

Tablo 6. 1896 Annuaire Oriental

\begin{tabular}{|l|l|}
\hline Zemin kat & $\begin{array}{l}\text { 9.Sayim Dahr (Ibrahim), tüccar- komis- } \\
\text { yoncu. }\end{array}$ \\
\hline No 2. Zenguianli (Aghadjan), halı. & $\begin{array}{l}\text { 10,11. Selim Kassap Zadé Effendi, ko- } \\
\text { misyoncu }\end{array}$ \\
\hline $\begin{array}{l}\text { No 3. Tophanelian (H.), oryantel merak- } \\
\text { lss. }\end{array}$ & 12,13. Kazazian (D.), imalatç1. \\
\hline 4,5. Habis (Ph.), oryantel meraklısı. & 14. Iekmalian (A.), kahve. \\
\hline 6,7,8. Camayor (S.), oryantel meraklıs1. & 15,16. Beglian (G.) Fréres, halı. \\
\hline 1.Kat & \\
\hline 18. Babani Fréres, oryantel meraklıs1. & 27. Altchidjian (M.), altın. \\
\hline 22. Sakayan (Gabriel), terzi. & 29. Kazazian (Garabet), tüccar. \\
\hline 23. Azarian (Stepan), tasarımc1. & 30. Hadji Omer, çay satıcis1 \\
\hline 24. Tehizmédjian (Lév.), imalatç1. & 31. Minassian (Boghos), kundurac1. \\
\hline 25. Maymon (R.), oryantal nakışç1. & 32. Hadji Mohammed, ince boyama. \\
\hline 26. Bezazian (Mardik), ipek. & 33.Allahverdian (Z.), perdeci \\
\hline 2.Kat & \\
\hline $\begin{array}{l}\text { 36. Camayor (Robert), oryantel merak- } \\
\text { lis1. }\end{array}$ & 52. Hassan Djemal, komisyoncu. \\
\hline 50. Courian (Paul), halı. & \\
\hline $\begin{array}{l}\text { Odabaş1: Tzacouropoulos (Costis) } \\
\text { Hussein Effendi. }\end{array}$ & \\
\hline
\end{tabular}

1898 Annuaire Oriental yıllığında odabaşının değiştiği dikkat çeker (Tablo 7). 
Tablo 7. 1898 Annuaire Oriental

\begin{tabular}{|l|l|}
\hline Zemin kat & \\
\hline $\begin{array}{l}\text { No 4. Menassé (E.M.), oryantel merak- } \\
\text { lis1. }\end{array}$ & 12,13. Kazazian (D.), imalatçı. \\
\hline No 6,8. Zenguianli (Aghadjan), halı. & 14. Indjian (A.), kahve. \\
\hline $\begin{array}{l}\text { 9.Sayim Dahr (Ibrahim), tüccar- komis- } \\
\text { yoncu. }\end{array}$ & 15,16. Beglian (G.) Fréres, halı. \\
\hline 1.Kat & \\
\hline 18. Mehmed Hussein Djemali, tüccar. & 29. Kazazian (Garabet), tüccar. \\
\hline 25. Maymon (R.), oryantal nakışçı. & 30. Hussein Effendi, tüccar. \\
\hline 26. Bezazian (Mardik), ipek. & 31. Minassian (Boghos), kunduracı. \\
\hline 27. Altchidjian (M.), altın. & \\
\hline 2.Kat & \\
\hline $\begin{array}{l}\text { 36. Camayor (Robert), oryantel merak- } \\
\text { lis1. }\end{array}$ & 58. Hassan Djemal, komisyoncu. \\
\hline Odabaş1: Hussein Effendi. & \\
\hline
\end{tabular}

1900 Annuaire Oriental yıllığında, ipek ve kumaş satıcısı ile giyim üreticilerinin satış yaptığ 1 görülmektedir. Odabaşı bu yıl tekrar değişmiştir (Tablo 8) .

Tablo 8. 1900 Annuaire Oriental

\begin{tabular}{|l|l|}
\hline Zemin kat & \\
\hline No 2. Epremian (D.), halı. & 12. Kazazian (D.), imalatç1. \\
\hline 4. Benhasson, halı. & 13. Nacouz (Basil), tüccar. \\
\hline 6,8. Habis (Phillippe M.), bayan giyim. & 14. Indjian (A.), kahve. \\
\hline $\begin{array}{l}\text { 9.Sayim Dahr (Ibrahim), tüccar- komis- } \\
\text { yoncu. }\end{array}$ & 15,16,24. Benlian (G.) Fréres, halı. \\
\hline 11. Carmona, oryantel meraklıs1. & \\
\hline 1.Kat & \\
\hline 18. Mehmed Hussein Djemali, tüccar. & 27. Ahmed Effendi Arab.türk parfümü. \\
\hline 18. Hussein Effendi, tüccar. & 29. Balit Fréres Halepli, tüccar. \\
\hline 24. Kazazian (Garabet), tüccar. & 35. Palombo, oryantel meraklıs1. \\
\hline 26. Benzonana, oryantel meraklis1. & \\
\hline 2.Kat & \\
\hline 22. Camayor (Robert), oryantel meraklıs1. & 27. Hassan Djemal, komisyoncu. \\
\hline Odabaş1: Moustapha Effendi. & \\
\hline
\end{tabular}


1901-1902-1903 Annuaire Oriental yıllıklarında, her kata ait kullanıcılar belirlenmiştir. Sabit meslek gruplarının yanı sıra her yıl değişen yeni meslek grupları dikkat çekmektedir (Tablo 9, Tablo 10, Tablo 11).

Tablo 9. 1901 Annuaire Oriental

\begin{tabular}{|l|l|}
\hline Zemin kat & \\
\hline No 1,10. Madjar (Isaac V.), nevresimci. & 6,8. Habis (Phillippe M.), bayan giyim. \\
\hline 2. Epremian (D.), halı. & $\begin{array}{l}\text { 9.Sayemel Dahr (Ibrahim), tüccar- ko- } \\
\text { misyoncu. }\end{array}$ \\
\hline 4. Ben Hasson, halı. & 11. Carmona, oryantel meraklısı. \\
\hline 5. Chaya (A.), oryantel meraklısı. & 12. Kazazian (D.), imalatçı. \\
\hline 14.Evrenian Fréres, halı. & 15,16. Benlian (G.) Fréres, halı. \\
\hline 1.Kat & \\
\hline 19. Hussein Effendi, tüccar. & 26. Benzonana, oryantel meraklıs1. \\
\hline 20. Abdulrahim Achouroil, komisyoncu. & 27. Hassan Effendi, türk parfümü. \\
\hline $\begin{array}{l}\text { 22. Camayor (Robert), oryantel merak- } \\
\text { 1s1. }\end{array}$ & 29. Balit Fréres Halepli, tüccar. \\
\hline 23. Sakayan (Gabriel), terzi. & 30. Kurkdji (Georgi), avukat. \\
\hline 24. Kazazian (Garabet), tüccar. & 31. Tabbalı Fréres, iran halıları. \\
\hline 2.Kat & \\
\hline 35. Palombo, oryantel meraklıs1. & 43.Loisoponlos (Georges), terzi. \\
\hline 40. Rabib Effendi, komisyoncu. & \\
\hline Odabaş1: Moustapha Effendi. & \\
\hline
\end{tabular}


Tablo 10. 1902 Annuaire Oriental

\begin{tabular}{|c|c|}
\hline Zemin kat & \\
\hline No 1,10. Madjar (Isaac V.), nevresimci. & $\begin{array}{l}\text { 9.Sayemel Dahr (Ibrahim), tüccar- ko- } \\
\text { misyoncu. }\end{array}$ \\
\hline 2. Epremian (D.), halı. & 12. Kazazian (D.), imalatçı. \\
\hline 4. Carmona, oryantel meraklısı. & $\begin{array}{l}\text { 14. Camayor (Robert), oryantel merak- } \\
\text { lis1. }\end{array}$ \\
\hline 5. Chaya (A.), oryantel meraklısı. & 15,16. Benlian (G.) Fréres, halı. \\
\hline 6,8. Habis (Phillippe M.), bayan giyim. & \\
\hline 1.Kat & \\
\hline 19. Hussein Effendi, tüccar. & 26,31. Habis, Şam makalecisi. \\
\hline 23. Sakayan (Gabriel), terzi. & $\begin{array}{l}\text { 27. Hassan Effendi Djemali Zade, tüc- } \\
\text { car. }\end{array}$ \\
\hline 24. Kazazian (Garabet), tüccar. & 30. Kurkdji (Georgi), avukat. \\
\hline 28. Abdulrahim Achouroil, komisyoncu. & \\
\hline 2.Kat & \\
\hline 35. Palombo, oryantel meraklisı. & \\
\hline Odabaşı: Moustapha Effendi. & \\
\hline
\end{tabular}

Tablo 11. 1903 Annuaire Oriental

\begin{tabular}{|l|l|}
\hline Zemin kat & \\
\hline No 1,11. Madjar (Isaac V.), nevresimci. & $\begin{array}{l}\text { 9.Sayemel Dahr (Ibrahim), tüccar- ko- } \\
\text { misyoncu. }\end{array}$ \\
\hline 2. Epremian (D.), halı. & 12. Kazazian (D.), imalatçı. \\
\hline 4. Carmona, oryantel meraklısı. & 14. Camayor (Robert), oryantel nakış̧1. \\
\hline 5. Chaya (A.), oryantel meraklısı. & 15,16. Benlian (G.) Fréres, halı. \\
\hline 6,8. Balit Fréres, bayan giyim. & \\
\hline 1.Kat & \\
\hline 19. Hussein Effendi, tüccar. & 26,31. Habis, bayan giyim. \\
\hline 22. Sakayan (Gabriel), terzi. & $\begin{array}{l}\text { 27. Hassan Effendi Djemali Zade, tüc- } \\
\text { car. }\end{array}$ \\
\hline 23. Vidal (Fils de H.), hal1. & 28. Abdulrahim Achouroil, komisyoncu. \\
\hline 24. Kazazian (Garabet), tüccar. & \\
\hline Odabaş1: Moustapha Effendi. & \\
\hline
\end{tabular}


1904-1905-1909-1912-1913-1914-1921 Annuaire Oriental yıllıklarında,meslek grupları tanımlanarak listelenmiştir. (Tablo 12, Tablo 13, Tablo 14, Tablo 15, Tablo 16, Tablo 17, Tablo 18)

Tablo 12. 1904 Annuaire Oriental

\begin{tabular}{|l|l|}
\hline No 1. Madjar (Isaac V.), nevresimci. & 14. Camayor (Robert), oryantel nakış̧ı. \\
\hline 4. Carmona, oryantel meraklısı. & 15,16. Benlian (G.) Fréres, halı. \\
\hline 5. Chaya (A.), oryantel meraklısı. & 19. Hussein Effendi, tüccar. \\
\hline 6,8. Habis (Phillippe M.), bayan giyim. & 22. Sakayan (Gabriel), terzi. \\
\hline $\begin{array}{l}\text { 9.Sayemel Dahr (Ibrahim), tüccar- ko- } \\
\text { misyoncu. }\end{array}$ & 23. Vidal (Fils de H.), halı. \\
\hline 11. Epremian (D.), halı. & 24. Kazazian (Garabet), tüccar. \\
\hline 12. Kazazian (D.), imalatç1. & $\begin{array}{l}\text { 27. Hassan Effendi Djemali Zade, tüc- } \\
\text { car. }\end{array}$ \\
\hline 13. Evlenian (Agop), halı. & 28. Abdulrahim Achouroil, komisyoncu. \\
\hline Odabaş1: Moustapha Effendi. & \\
\hline
\end{tabular}

Tablo 13. 1905 Annuaire Oriental

\begin{tabular}{|l|l|}
\hline No 1. Madjar (Isaac V.), nevresimci. & 14. Camayor (Robert), oryantel nakış̧̧1. \\
\hline 4. Carmona, oryantel meraklısı. & 15. Benlian (G.) Fréres, halı. \\
\hline 5. Chaya (A.), oryantel meraklısı. & 16. Abadjian (Artin P.), tüccar. \\
\hline 6,8. Habis (Phillippe M.), bayan giyim. & 22. Sakayan (Gabriel), terzi. \\
\hline 11. Epremian (D.), halı. & 24. Kazazian (Garabet), tüccar. \\
\hline 12. Kazazian (D.), imalatç1. & $\begin{array}{l}\text { 27. Hassan Effendi Djemali Zade, tüc- } \\
\text { car. }\end{array}$ \\
\hline 13. Sislian (Stepan), halı. & 28. Abdulrahim Achouroil, komisyoncu. \\
\hline Odabaş1: Ruchdi Effendi. & \\
\hline
\end{tabular}


Tablo 14. 1909 Annuaire Oriental

\begin{tabular}{|l|l|}
\hline $\begin{array}{l}\text { No 4. Havloudjian (Levon), iç çama- } \\
\text { şırcı. }\end{array}$ & 20. David (Avram), nakışçı. \\
\hline 5. Chaya (A.), oryantel meraklısı. & 21. Sabbagh (Gabriel), terzi. \\
\hline 6,8. Habis (Phillippe M.), bayan giyim. & 22. Sakayan (Gabriel), terzi. \\
\hline 11. Epremian (D.), halı. & 26. Stepan Agha, nakışçı. \\
\hline $\begin{array}{l}\text { 13. Taslakdjian (Sétrak M.), komis- } \\
\text { yoncu. }\end{array}$ & 27. Hassan Djemali Zade, tüccar. \\
\hline $\begin{array}{l}\text { 14. Skonfopoulos (Georges), bayan } \\
\text { konfeksiyon. }\end{array}$ & 28. Abdulrahim Achouroil, komisyoncu. \\
\hline \begin{tabular}{l} 
15,16. Sarian (Benjamin), halı. \\
\hline Odabaş1: Mehmed İhsan.
\end{tabular} & 30,31. Rachid Osman, iç çamaşırc1. \\
\hline
\end{tabular}

Tablo 15. 1912 Annuaire Oriental

\begin{tabular}{|l|l|}
\hline $\begin{array}{l}\text { No 2. Havloudjian (Levon), iç çama- } \\
\text { şrcı. }\end{array}$ & 21. Der Zacarian (S.), tüccar. \\
\hline 4. Epremian (D.), halı. & 22. Sakaian (Gabriel), terzi. \\
\hline 5. Chaya (A.), oryantel meraklısı. & 26. Azarian (Stepan), nakışçı. \\
\hline $\begin{array}{l}\text { 6,8. Rahvandji Zade M. Sadik, bayan } \\
\text { giyim. }\end{array}$ & 27. Hassan Djemali Zade, tüccar. \\
\hline $\begin{array}{l}\text { 9.Sayemel Dahr (Ibrahim), tüccar- ko- } \\
\text { misyoncu. }\end{array}$ & 28. Abdulrahim Achouroil, komisyoncu. \\
\hline $\begin{array}{l}\text { 11. Said Mehmed, kadın konfeksiyon- } \\
\text { cusu. }\end{array}$ & 29. Rachid Osman, iç çamaşırcı. \\
\hline $\begin{array}{l}\text { 13. Taslakdjian (Sétrak M.), komis- } \\
\text { yoncu. }\end{array}$ & 35. Yervantian( Boghos), komisyoncu \\
\hline $\begin{array}{l}\text { 14. Skonfopoulos (Georges), bayan } \\
\text { konfeksiyon. }\end{array}$ & 42. Sivadjian, oryantel nakışçı. \\
\hline $\begin{array}{l}\text { 15. Hadji Abdullah Zade Mehmed, iç } \\
\text { çamaşrcı }\end{array}$ & 44. Emin Effendi Ferra,komisyoncu. \\
\hline 20. Koenigfest Fréres, oryantel nakışçc1. & $\begin{array}{l}\text { 45. Hussein Tehaouche Mehmed, halı } \\
\text { satıcısı. }\end{array}$ \\
\hline Odabaşı: Mehmed İhsan. & \\
\hline
\end{tabular}


Tablo 16. 1913 Annuaire Oriental

\begin{tabular}{|l|l|}
\hline No 2.Sayemel Dahr (Ibrahim), tüccar. & $\begin{array}{l}\text { 21. Der Zacarian (S.), altın dantel ve } \\
\text { ipekçi. }\end{array}$ \\
\hline 3. Havloudjian (Levon), iç çamaşırcı. & 22. Sakaian (Gabriel), terzi. \\
\hline 4. Epremian (D.), halı. & 23. Mihtchivakian (Ohannes), halı. \\
\hline 5. Chaya (A.), oryantel meraklısı. & $\begin{array}{l}\text { 26. Azarian (Stepan), keten üzerine dam- } \\
\text { gacı. }\end{array}$ \\
\hline $\begin{array}{l}\text { 6,8. Rahvandji Zade M. Sadik, bayan gi- } \\
\text { yim. }\end{array}$ & $\begin{array}{l}\text { 27. Mehmed Hassan Djemali Zade, tüc- } \\
\text { car. }\end{array}$ \\
\hline $\begin{array}{l}\text { 11. Said Mehmed, kadın konfeksiyon- } \\
\text { cusu. }\end{array}$ & 28. Abdulrahim Achouroil, komisyoncu. \\
\hline $\begin{array}{l}\text { 12. Sivadjian, oryantel nakışç1. } \\
\text { 13. Taslakdjian (Sétrak M.), komisyoncu. }\end{array}$ & $\begin{array}{l}\text { 29. Osman Rachid, iç çamaşırcı. } \\
\text { maşırcı. }\end{array}$ \\
\hline $\begin{array}{l}\text { 14. Skonfopounian et Varteressian, iç ça- } \\
\text { feksiyon. }\end{array}$ & 37. Yervantian( Boghos), komisyoncu \\
\hline 15. Aslanian Fréres, oryantel halıcı. & 44. Emin Effendi Ferra,komisyoncu. \\
\hline 20. Koenigfest Fréres, oryantel nakış̧ı. & $\begin{array}{l}\text { 45. Hussein Tehaouche Mehmed, halı sa- } \\
\text { tıcısi. }\end{array}$ \\
\hline Odabaş1: Mehmed İhsan. & \\
\hline
\end{tabular}

Tablo 17. 1914Annuaire Oriental

\begin{tabular}{|l|l|}
\hline No 2.Sayemel Dahr (Ibrahim), tüccar. & $\begin{array}{l}\text { 21. Der Zacarian (S.), altın dantel ve } \\
\text { ipekçi. }\end{array}$ \\
\hline 4. Epremian (D.), halı. & 22. Sakaian (Gabriel), terzi. \\
\hline 5. Chaya (A.), oryantel meraklısı. & 23. Papazian (Sepon), komisyoncu. \\
\hline 6,8.RahvandjiZadeM.Sadik, bayangiyim. & 24. Osman Rachid, iç çamaşı̈rcı. \\
\hline 9. Havloudjian (Levon), iç çamaşırc1. & $\begin{array}{l}\text { 26. Azarian (Stepan), keten üzerine dam- } \\
\text { gacı. }\end{array}$ \\
\hline 11.SaidMehmed,kadınkonfeksiyoncusu. & 28. Abdulrahim Achouroil, komisyoncu. \\
\hline 12. Sivadjian, oryantel nakışçı. & 29. Adalian (Diran), oryantel nakışçı \\
\hline 13. Taslakdjian (Sétrak M.), komisyoncu. & 31. Apissoghomian (Apig), altın. \\
\hline 14. Cohen (Isaac), bayan giyim. & $\begin{array}{l}\text { 32. Der Aharonian et Varteressian, iç ça- } \\
\text { maşırcı. }\end{array}$ \\
\hline 15. Habis (Filip), oryantel meraklısı. & 37. Mosés (Joseph), kumaşç1. \\
\hline 20. Koenigfest Fréres, oryantel nakışç1. & $\begin{array}{l}\text { 45. Hussein Tehaouche Mehmed, halı sa- } \\
\text { tıcısi. }\end{array}$ \\
\hline Odabaş1: Mehmed İhsan. & \\
\hline
\end{tabular}


Tablo 18. 1921 Annuaire Oriental

\begin{tabular}{|l|l|}
\hline Zemin kat & \\
\hline No 8. Cupéyan (Dieran), bayi. & 12,13. Kardachian (Garabed), bayi. \\
\hline 10. Papazian, imalaţ̧1. & $\begin{array}{l}\text { 14,15,16. Kazandjian (Bedros), halı ve } \\
\text { ipek. }\end{array}$ \\
\hline 11. Cheres (Bension), halı tüccarı. & \\
\hline 1. kat & \\
\hline 20. Husni Hussein, avukat & 28,29. Simeonidis(Simeon), eczane. \\
\hline 23. Mafidis (Nie.),terzi. & \\
\hline 2. kat & \\
\hline 37. Paksevadian (V.), avukat. & 44. Mitsatsi (Haim), halı. \\
\hline 38. Japhet (A.), tüccar, komisyoncu. & 46. Havloudjian (Noubar), imalatç1. \\
\hline 41. Sivadjian (A.), avukat. & 47. Baghdassarian (Baghdassar), giyim. \\
\hline 42. Boniguian (A.), tüccar, komisyoncu. & 49. Atarian (Armenak), bayan giyim. \\
\hline 43. Deirmendjian (Lévon), avukat. & 51. Fintzi (Nissim D.), bayi. \\
\hline
\end{tabular}

\subsection{Vakıflar dergisi}

Literatür araştırması sonucu Yarım Han yapısının vakıf hanı olduğu Mehmet Sadettin Fidan'ın Geçmişten Günümüze İstanbul Hanları yayınında belirlenmiş olup, kaynağın aslı olan Vakıflar Dergisinin 10. Sayısında Fazıl Işıközü'nün İstanbul'un Eski Vakıf Hanları yazısındaki listede hangi vakfa ait olduğu karşımıza çıkmıştır. (Şekil 19). 


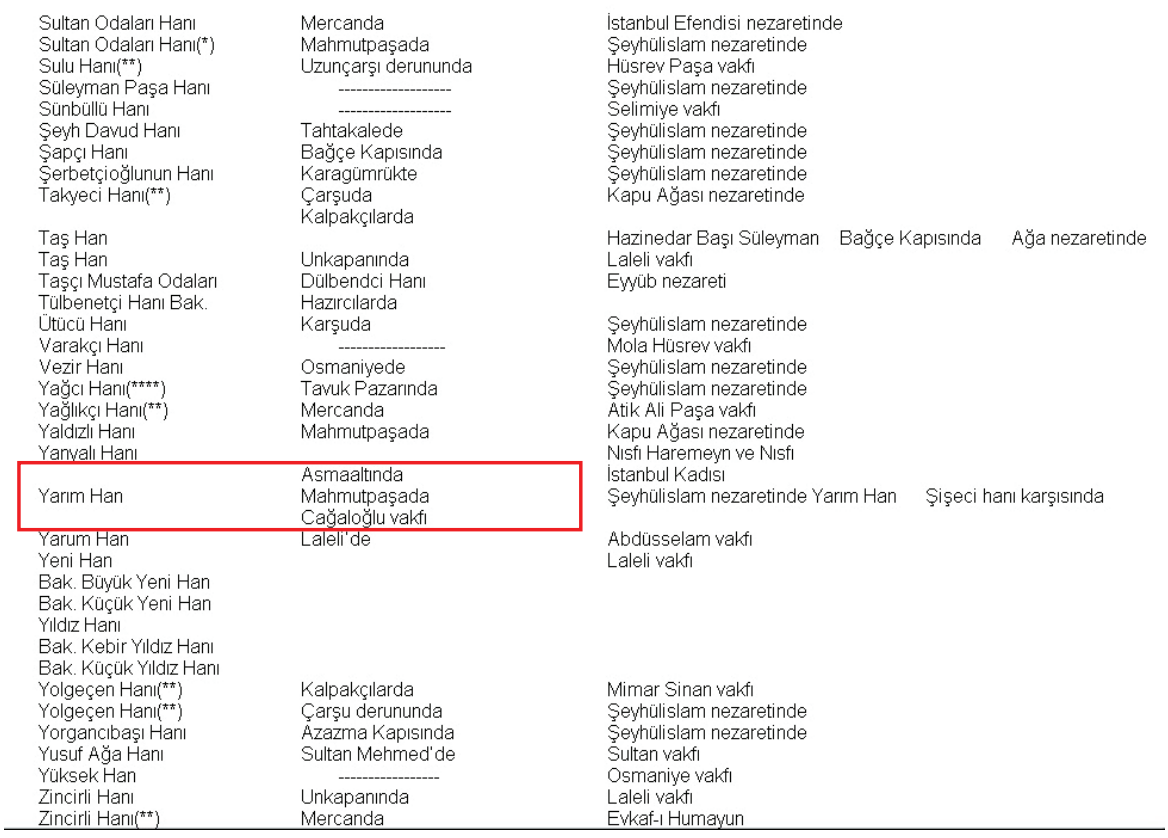

Şekil 19. Vakıflar Dergisi 10. Sayısı.

\section{Yarım Han'ın çağdaş örnekleri ile karşılaştırılması}

\subsection{Caferiye Han}

Eminönü, Mercan Ağa Mahallesinde Mercan Caddesi üzerinde bulunan hanın yapım tarihi 1888 dir (Şekil 20). Zemin kattaki dükkân düzenlemeleri nedeniyle, özgün vitrin ve doğramalarını kaybetmiştir. Yarım Han yapısına benzer bir biçimde geniş bir iç avluya ve bu avlu çevresinde sıralanmış odalar/dükkânlardan oluşmaktadır. Bu avlu nedeniyle Klasik Osmanlı hanı olarak görülmesine rağmen, kullanılan volta döşemeler ile galeri boşluğunu taşıyan dökme demir sütunlar nedeniyle geçiş hanı özelliği sağlamaktadır. 

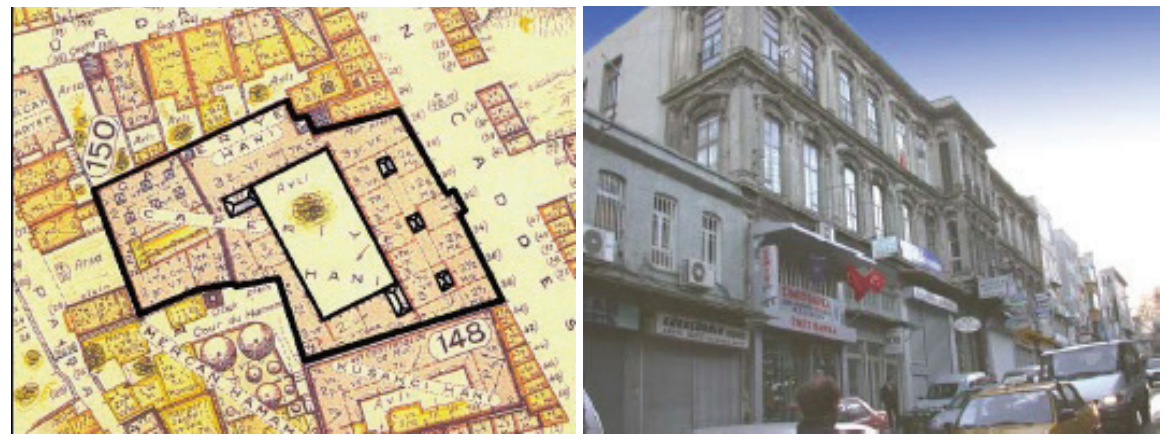

Şekil 20.Caferiye Han(Mimar Nil Köroğlu Yüksek Lisans Tezi)

\subsection{Giritli Mustafa Paşa Hanı}

Eminönü, Mercan Ağa Mahallesinde, Çakmakçılar Yokuşu ile Fincancılar Sokağı'nın kesiştiği köşe parselinde yer almaktadır. 1868 ticari yıllıklar incelendiğinde izine rastlanıldığından ötürü, bu tarihten hemen önce yapıldığ 1 düşünülmektedir. Vaziyet planı olarak incelendiğinde, Yarım Han gibi köşe parselde yer aldığ1, ancak tek bir sokaktan girişinin olduğu görülmektedir. Bir iç avlu ile bu avluya açılan dükkânlar sıralı bir biçimde konumlanmıştır. Avluyu çevreleyen galeri boşluğunun üstü, Yarım Han gibi bir cam örtü ile kapatılmıştır. Planlaması ve cephe özellikleri bakımından klasik Osmanlı Hanlarını anımsatsa da, galeri boşluğu, dökme demir sütunlar ile volta döşemelerinin olması geçiş dönemi hanı olduğunu yansıtmaktadır (Şekil 21). 

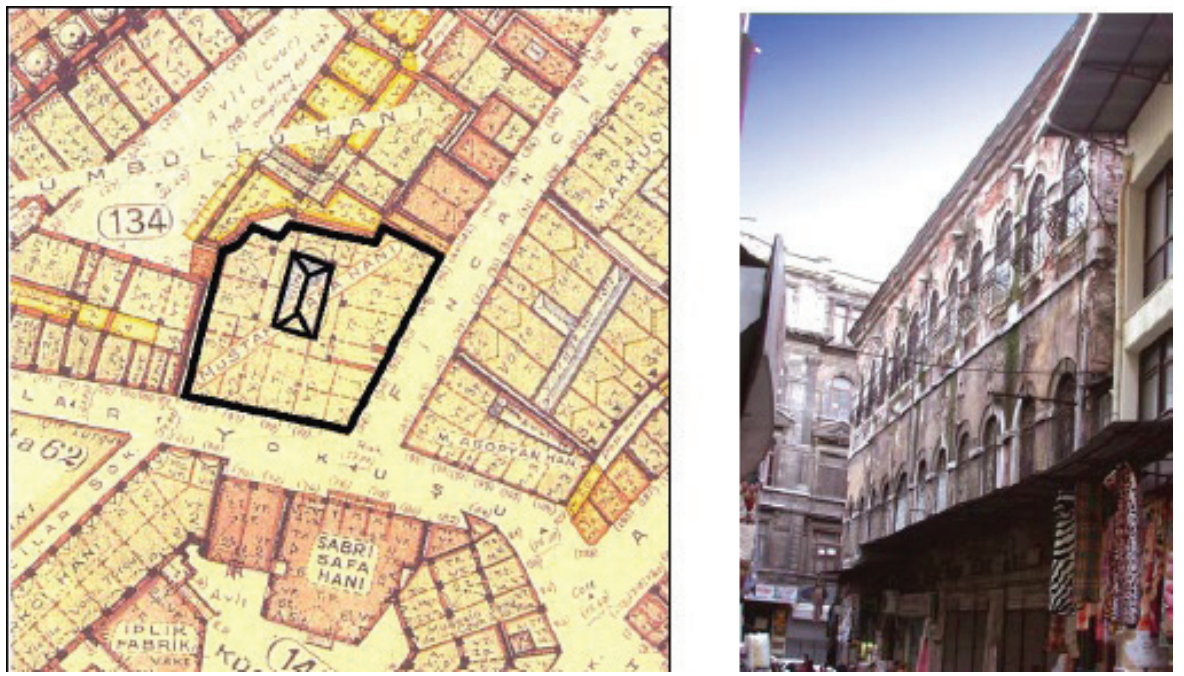

Şekil 21. Giritli Mustafa Paşa Hanı (Mimar Nil Köroğlu Yüksek Lisans Tezi)

\subsection{Büyük Abud Efendi Han( Abboud Effendi Han)}

Eminönü, Çelebioğlu Mahallesi, Marpuççular Caddesi No 27'deki bu han bitişik nizamlıdır. 1887' de Abud Efendi tarafından yaptırılmış olan han, zeminle birlikte dört katlı olup ayrıca bir bodrumu ve çatı katı vardır. Dikdörtgen bir avlu etrafında düzenlenmiştir. Üstü dört yana eğimli cam bir çatı ile örtülüdür. Büyük Abud Efendi Han'ın Marpuççular Caddesi üzerinde tek cephesi oldukça süslüdür. Neo-Barok ağırlıklı eklektik üsluptaki cephenin zemin katında pilastrlar arasında dükkân kapı ve vitrinleri görülür. Dikdörtgen bir açıklık şeklindeki han girişi ile avlu arasında üzeri volta döşemeli bir geçit bulunur. Sokak tarafındakiler hariç tüm zemin kat dükkânları bir kapı ve iki pencereyle avluya açılır. Birinci katta avlu açıklığının dört tarafı bir galeri ile çevrilidir. Dökme demir korkuluklu galerinin tabanında tabanından tavanına kompozit başlıklı ince demir sütunlar uzanır. Galerinin yerleri çini, tavanı odalar gibi volta döşemedir. Odalar galeriye dikdörtgen söveli bir kapı ve pencere ile açılır. Cephe bezemeleri 
bakımından oldukça benzerlik gösterdiği Yarım Han gibi, volta döşemelere sahip, galeriye kapı ve pencereler ile açılan sıralı dükkânların yer alması da aynı dönem özelliklerini taşıdığını kanıtlamaktadır. 1889-90 ticaret yıllıklarında görülmektedir (Şekil 22).
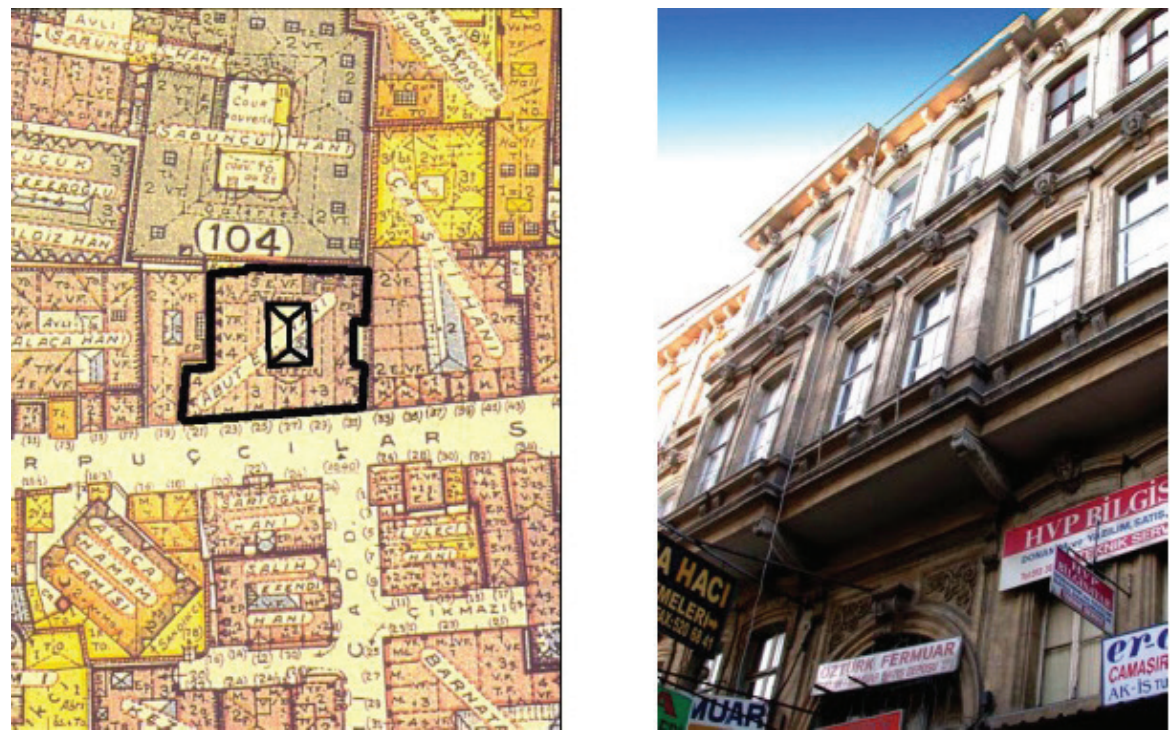

Şekil 22. Büyük Abud Efendi Han(Mimar Nil Köroğlu Yüksek Lisans Tezi)

\subsection{Mahmudiye Han (Mahmoddie Han)}

Eminönü, Mercan Mahallesi, Fincancılar Sokak No 25,27'deki Mahmudiye Han bitişik nizamda yapılmıştır. Kitabesi olmayan ve yazılı kaynaklarda da yapım tarihine rastlanmayan bu han, yap1 elemanları ve üslup itibariyle 19. Yüzyıl sonunda yapılmış olmalıdır. Ayrıca, 1893-94 yılına ait ticaret yıllıklarında adının geçiyor oluşu bu tarihten önce yapıldığına işaret etmektedir. Kareye yakın bir plana sahip olan Mahmudiye Han bodrum hariç dört katlıdır, ayrıca bir de çatı katı vardır. Ortasında kareye yakın planlı, üzeri cam çatılı bir avlu bulunur. Cam çatı dört yana eğimlidir. Odalar zemin katta doğrudan 
avluya, üst katlarda avlu boşluğunun dört tarafinı çeviren galeriye aç11ır. Üzeri volta döşeme bir geçitten dükkânlarla çevrili olan avluya girilir. Odaların dışarı açılan pencereleri içeriden, avluya açılan kapı ve pencereleri hem içeriden hem de dışarıdan dikdörtgen sövelidir. Kapı ve pencerelerin dökme demir kanatları halen bazı odalarda muhafaza edilmiştir (Şekil 23).
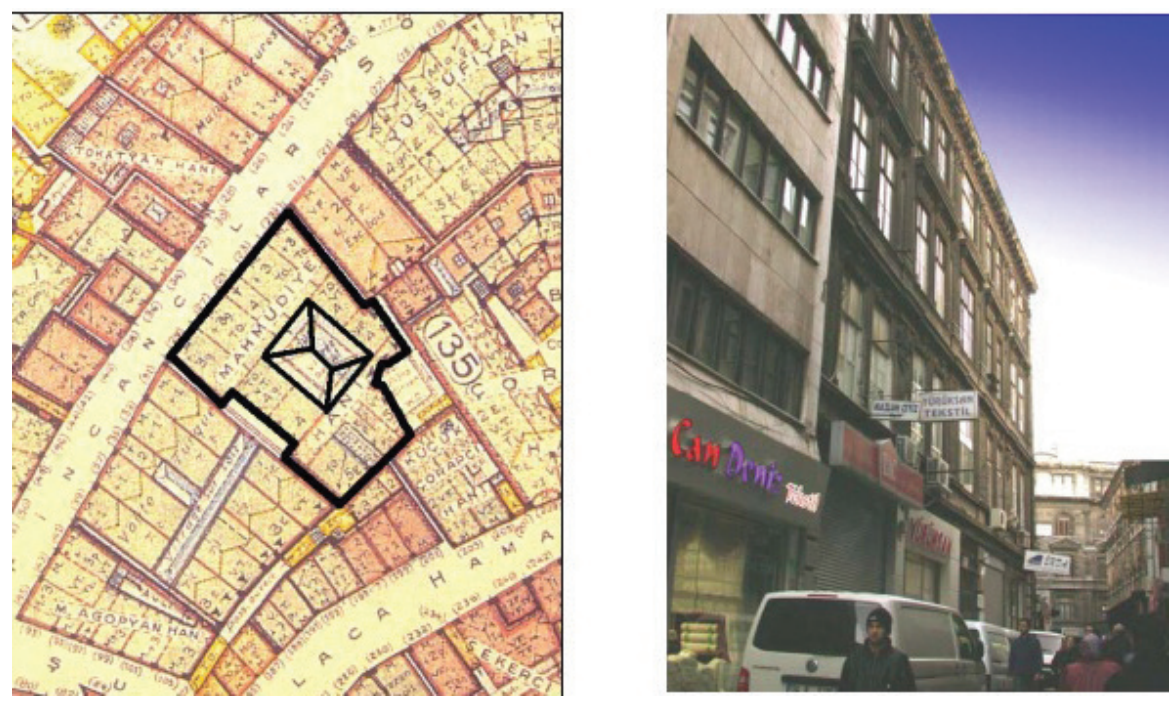

Şekil 23. Mahmudiye Han(Mimar Nil Köroğlu Yüksek Lisans Tezi)

\section{Yarım Han Yapısının Restitüsyon Önerisinin Hazırlanması}

Yapının restitüsyon önerisi 20. yüzyıl başındaki durumuna göre hazırlanmıştır. Tüm katlarda dükkan mekanlarını genişletmek amacıyla, hücreler arası geçiş boşluklarının düzensizliği sorununa karşılık, yapı izlerinin ve 1940 tarihli Pervititch sigorta haritası) plan çiziminin irdelenmesi ile bu boşlukların kapatılarak özgün kullanımın getirilmesi önerilmiştir. Buna göre hücre bölümlemeleri özgün hacimlerine ulaşırken, yapının 1şıklık alanları içinde bulunan ve dükkanların asma kata ulaşmaları için uyguladıkları merdivenlerin kaldırılması istenilmiştir. 
İkinci kattaki farklı hücrelere ait özgün pencere ve kapı doğramaları zemin ve birinci katta özgün olmayan doğramalar yerine önerilmiştir (Şekil 24).

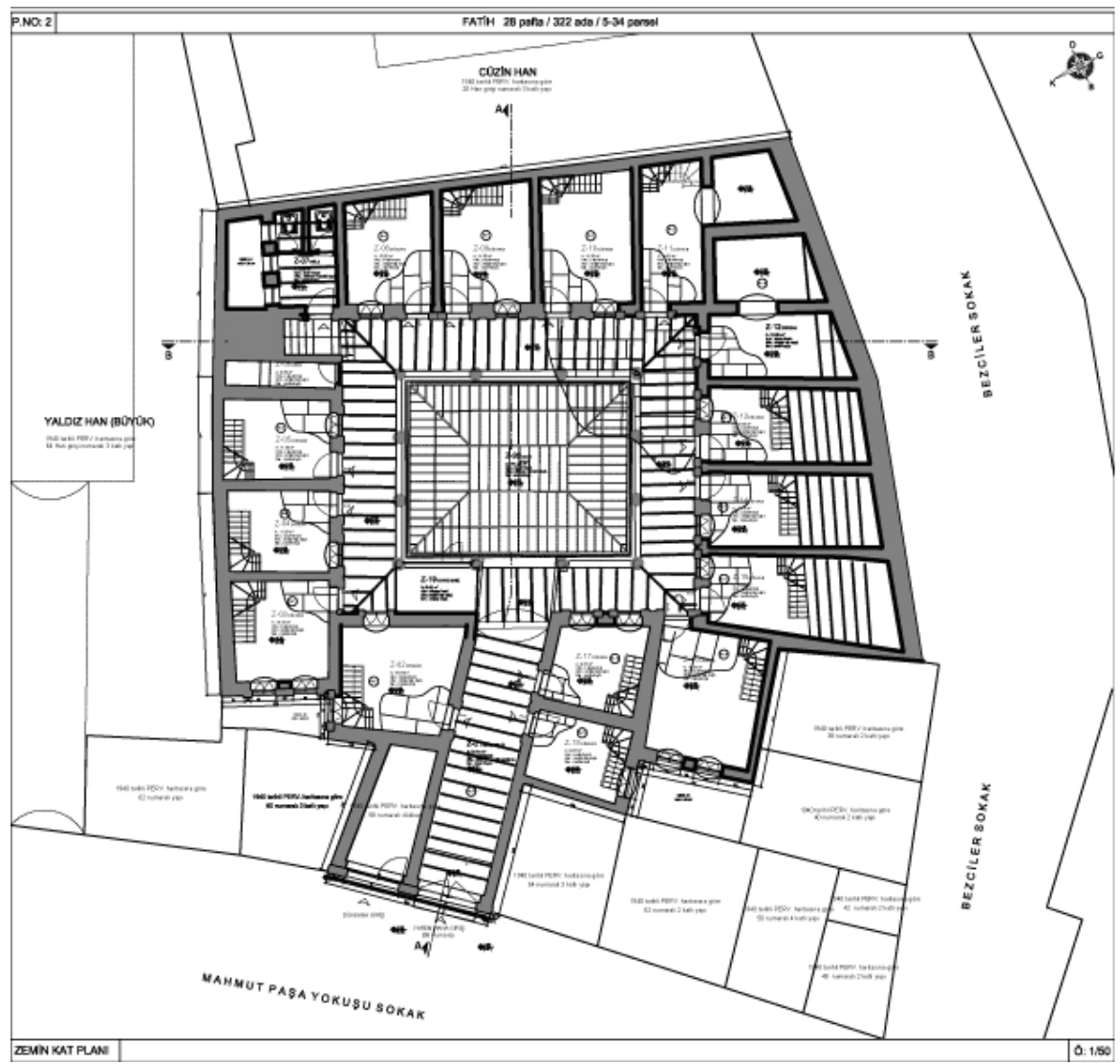

Şekil 24. Yarım Han Zemin Kat Planı Restitüsyonu(Öztekin, 2016)

Çatı planında ise Encümen Arşivi'ne ait 1940 yılına ait Yarım Han çatı fotoğrafi ve 1966 Hava Fotoğrafından da faydalanılarak, özgün olmayan teras çatı kullanımı yerine kırma çatı önerisi geliştirilmiştir (Şekil 13, Şekil 14, Şekil 25, Şekil 26). 


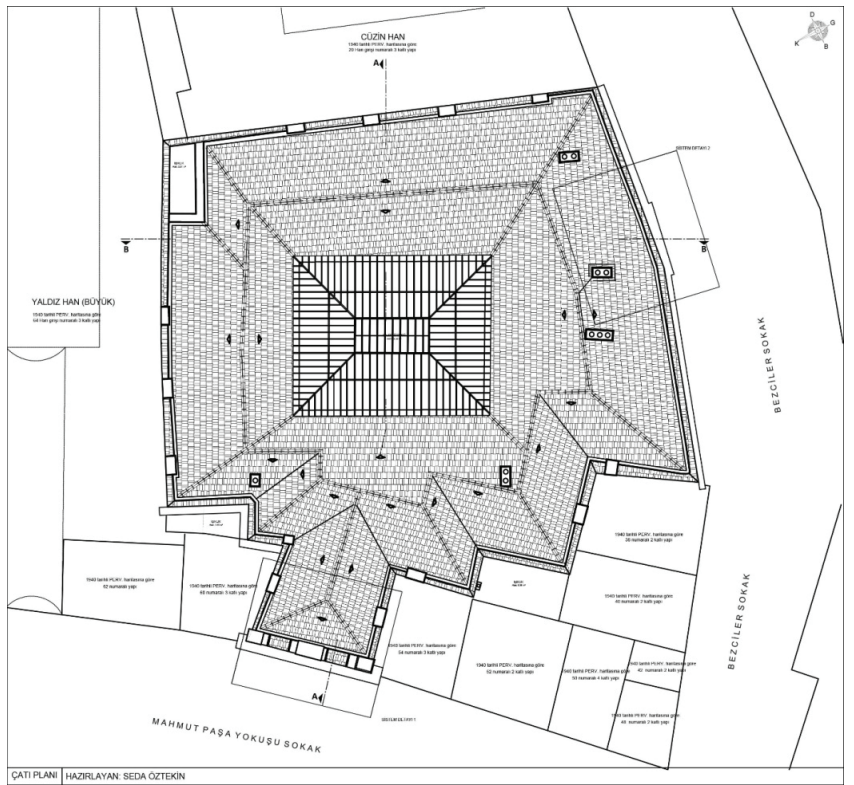

Şekil 25. Yarım Han Çatı Planı Restitüsyonu(Öztekin, 2016)

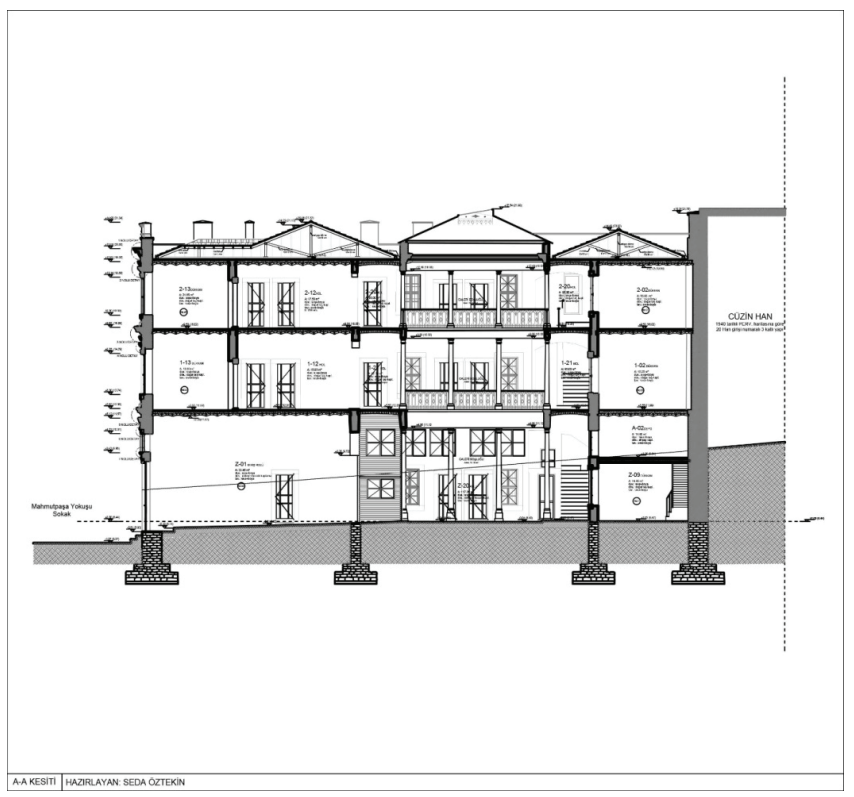

Şekil 26. Yarım Han A-A Kesiti Restitüsyonu(Öztekin, 2016). 
Yarım Han yapısının cephe ile ilgili zorlayıcı bir restitüsyon problemi bulunmamaktadır. Ancak, giriş kotlarında yer alan dükkânlardaki muhdes doğrama malzemeleri ve kepenkleri ile reklam panoları dikkat çekmektedir. Bu durum özgün Mahmutpaşa çarşı dokusunu bozmaktadır. Bezemeli olan ön cephede klima ünitelerinin yanı sıra, giriş kap1s1 üzerinde yer alan metal üst örtü dikkat çekmektedir. Bu cepheye bakan tüm pencerelerde görülen özgün olmayan niteliksiz demir parmaklık kullanılmıştır. Ayrıca pve ve alüminyum malzemeler kullanılarak pencereler yenilenmiştir.

Bezciler Sokak cephesindeki tüm reklam panoları ve vitrinler kaldırılarak, dükkân doğramaları ve kepenkleri tek tipte birbiriyle uyum içerisinde olmasına dikkat edilerek önerilmiştir. Diğer cephede olduğu gibi bu cephedeki tüm demir parmaklıklar kaldırılmıştır. Pencere doğramaları özgün ahşap pencere detayına uygun olarak değiştirilmesi önerilmiştir.

\section{Yarım Han Yapısının Restorasyonu}

Geleneksel çarşı dokusu içerisinde bulunun Yarım Han yapısında, işlev yine ticaret ve satış alanında devam edecektir. Mevcut kullanıcıları ve kiracıları koruyan bir yaklaşımla yeni restorasyon kararları alınmıştır. Restorasyon projesi öncesi, KUDEB Konservasyon ve Restorasyon Laboratuvarı uzmanları tarafından alınmış olan 1 adet ahşap, 2 adet taş, 2 adet sıva ve 1 adet harç örneğinin tanımları yapılmış, ve birim bu doğrultuda öneriler sunmuştur. Bu öneriler dikkate alınarak, yerinde koruma, bütünleme ve onarım ile yeniden üretim başlıkları altında yapı elemanları ve yapı malzemelerine öneriler getirilmiştir.

Rölöve çalışması sırasında yapılan hasar tespitleri doğrultusunda müdahale kararları oluşturulmuş ve bunun uygulama biçimlerine karar verilmiştir. 


\subsection{Müdahale kararları}

\subsubsection{Niteliksiz eklerin kaldırılması}

Han içinde iç avluya bakan dükkanlara ait kapı ve pencere doğramaları ile, Mahmutpaşa Yokuşu Sokağı ve Bezciler Sokak cephesine bakan dükkanlara ait doğramaların ve tabelaların kaldırılması uygun görülmüştür. Restitüsyon önerisi hazırlanırken, yapının kendi bünyesinde olan özgün ahşap pencere doğraması, kaldırılacak olanların yerine önerilmiştir. Dükkân doğrama ve kepenkleri için, yapının dönemine uygun olarak ahşap kayıtlı vitrin camı ve kapı detayı geliştirilmiştir (Şekil 27).

Han içinde kalan dükkânlara ait kapılar yerine, ikinci katta korunmuş demir kapı detayı incelenmiş ve benzerlerinin uygulanmasına karar verilmiştir. Yapının kimliğini bozan, asma tavan uygulamaları ve seramik kaplama malzemeleri yerine, avluda korunmuş olan doğal taş döşemeler önerilmiştir.

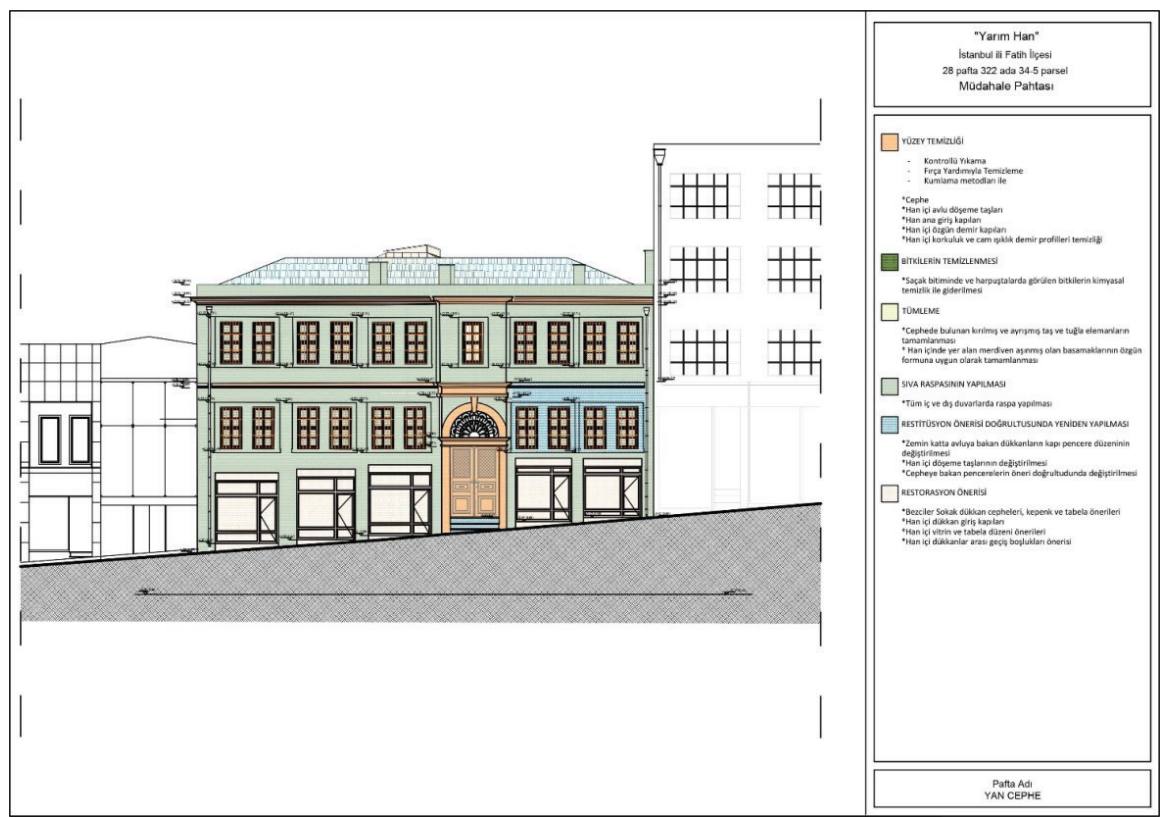

Şekil 27. Yarım Han Restorasyon Kararları (Öztekin, 2016) 


\subsubsection{Yüzey temizliği}

Temizleme yöntemi olarak su ile kontrollü yıkama ve kumlama tekniklerinin kullanılmasına karar verilmiştir. Buna göre, cephelerde bezemelerin olmadığı yüzeyler için su ile kontrollü yıkama ile temizleme önerilirken, bezemeli yüzeylerde herhangi bir yüzey erezyonu yaşanmaması adına fırça yardımıyla temizleme önerilmiştir. Yoğun kirlenme görülen, su ile kontrollü yıkamanın etkisinin görülmeyeceği yüzeylerde, kâğıt hamuru uygulaması başvurulacak bir yöntemdir.

Han içinde ise, avlu döşeme taşları, ana giriş kapıları, han içi özgün demir kapılar, korkuluk ve cam 1şıklık demir profillerinin temizliği için kumlama metodu ile temizlik yapılması kararları oluşturulmuştur.

\subsubsection{Bütünleme}

Cephede bulunan kırılmış ve ayrışmış taş ve tuğla elemanların tamamlanması önerisinin, KUDEP bünyesinde yapılan malzeme analizleri doğrultusunda yapılmasına karar verilmiştir. Buna göre, kırılmış taş elemanların onarımı ve bütünlenmesinde, ilgili taşın kimyasal ve mekanik özelliklerine uygun yeni bir elemanın uygulanması düşünülmüştür. Aynı şekilde, han içindeki özgün merdivenlerde görülen aşınmaların giderilmesi sırasında benzer bir yaklaşımla düzeltmeler yapılacaktır.

\subsubsection{Yangın merdiveni önerisi}

İtfaiye yönetmeliği gereği, her kata hizmet etmesi gereken bir açık bir de korunaklı merdiven şartı gereğince; mevcut merdiven mevcut olarak korunmuş olup, Bezciler Sokağı girişine hizmet eden basamakların korunaklı merdiven olarak kullanılması önerisi projede sunulmuştur. Buna göre, hanın birinci katına ulaşan basamakların devamı olarak alt kata inen bir merdiven ile aynı şekilde ikinci kata ulaşması 
planlanan merdiven ile bu şart sağlanmış olmaktadır. Zemin kat ve ikinci katta merdiven kovasına denk gelen dükkânlar korunaklı olduğundan yalnızca işlev değişikliği durumu söz konusudur. Birinci katta ise bu merdivenin kapatılmasının sebebi korunaklı hale getirilme zorunluluğundandır. Yeni önerilen merdiven günümüz çağdaş mimarisine uygun olarak çelik taşıyıcı ve basamaklardan oluşmaktadır. Taşıyıcı sistemi kendi bünyesinde olan merdivenin tarihi yapıya olan yükü en aza indirgenmiştir.

\section{Sonuç ve Değerlendirme}

Bu çalışma ile, tescilli bir kültür varlığı olan Yarım Han'a ait rölöve restitüyon ve restorasyon projesinin hazırlanması esnasında, belgeleme, alan gezisi, literatür araştırması, eski belge ve fotoğraf arşivlerinin araştırılması sonucu ulaşılan bilgilerin nasıl kullanılacağı yönünde bir derleme yapılmıştır. Yapının konumlandığı Eminönü- Hanlar Bölgesi'nin Osmanlı dönemindeki sosyo ekonomik ve mekânsal yapısı hakkında bilgi verilerek, ticari yapı türleri içinden hanlar ile han türleri incelenmiştir. 15. yüzyıl ile 19. Yüzyıl arasında değişiklik gösteren İstanbul Hanlar Bölgesi Osmanlı kent dokusu içerisinde çarşı kültürüne dair değerlere sahiptir. Bu bölge, yapıldığı dönemde kentin en canlı ve kültürel çeşitliliği gereği en hareketli bölge iken, 19.yüzyılda batılılaşma ile değişime uğramaya başlamıştır. Ancak, cumhuriyet dönemi ile değişen ve gelişen kent ekonomisine bağlı olarak yeni kent merkezlerinin oluşması sonucu, Eminönü ve Hanlar Bölgesi tek ticaret merkezi olma özelliğini kaybetmeye başlamıştır. Günümüzdeki durumuna bakıldığında, bütün değişimlerin etkisiyle birlikte fiziksel ve sosyal köhneleşmeye uğradığını söylemek mümkündür. Bölgenin bugün içinde bulunduğu sosyal ve fiziksel hasarlara bağlı olarak bu şartlardan kurtarılması adına pek çok proje yapılmış ve yapılmaktadır. Kentsel yenileme ve turistik bir amaca yönelirken yapılacak olan projelerde, bütünleşik koruma dahilinde önerilerin geliştirilmesi önemlidir. Geleneksel ticaret merkezi olarak işlevini sürdürmesi ve bunu 
bölgedeki yaşayanlar ile kullanıcıları ile birlikte olması bölgesel değeri içinde somut olmayan değerler ile birlikte sürdürülebilir olması amaçlanmalıdır.

Bölge içerisinde kalan tescilli yapıların korunmasına ek olarak, alan içerisinde tescilli yapılar dışında kalan diğer yapılar bütün içinde değerlendirilerek, işlev ve tasarım yaklaşımları hassasiyetle oluşturulmalıdır. Bölgede yer olan hanların koruma sorunları genel olarak, betonarme ekler, hana ek yapılması, oda aralarında geçiş boşluklarının açılması, asma tavan eklenmesi, özgün kaplama malzemeleri yerine niteliksiz onarımlarla müdahale edilmesi, oda kap1 ve pencerelerinin değiştirilmesi, kepenklerin kaldırılması ve yerine demir parmaklıkların eklenmesi, reklam tabelası, tente, vitrinlerin özgün form ve biçimlerinden oldukça uzak ürünlerle değiştirilmesidir. Koruma önerileri arasında, eklentilerden arındırma ve basit bakım onarım yaparak, cephe temizliği ve rehabilitasyona gidilmesi önemlidir. Tescilli yapıların korunması adına, detaylı bir rölöve, restitüsyon ve restorasyon projelerinin hazırlanması ile dönemine uygun özgün plan şeması, yapım tekniği, malzeme ve cephe özelliklerinin korunması, gelecek nesillere ilgili değerlerin taşınması açısından gereklidir.

19. Yüzyıl sonunda inşa edilmiş olan Yarım Han, yapıldığı dönemin malzeme ve yapım tekniklerinin açıkça görüldüğü, korunmuşluk değeri yüksek bir ticari yapı örneğidir. Yapının korunması adına, içinde bulunduğu geleneksel ticari aks, kullanıcı profili ve kültürü gibi somut ve somut olmayan değerler de gözetilmiştir. Bu değerleri kapsamında rölöve, restitüsyon ve restorasyon projesinin geliştirilmesi ve ilgili kurumlarca onaylanması ile Yarım Han yapısının geleneksel çarşı dokusu içerisindeki konumu ve kullanıcıları ile bir arada kullanımı sağlanmış olacaktır. 


\section{Kaynaklar}

[1] Batur, A. 'Geç Osmanlı Mimarlığında Betonarme Yapım Tekniği', İstanbul.

[2] Benli, G. 'İstanbul Tarihi Yarımada'da Bulunan Han Yapıları ve Avlulu Hanların Koruma Sorunları', Doktora Tezi, Yıldız Teknik Üniversitesi, İstanbul, 2007.

[3] Cantay, G. 'Hanlar', İstanbul Ansiklopedisi, Cilt: 3, 548-549-550, İstanbul, 1994.

[4] Fidan, M.S. 'Geçmişten Günümüze İstanbul Hanları'. İstanbul Ticaret Odası, Yayin no: 2009-20, İstanbul, 2009.

[5] Gülenaz, N. 'İstanbul'daki 19.Yüzyıl ve Sonrası Osmanlı Ticaret Han ve Pasajlarının Stil ve Fonksiyon Bakımından İncelenmesi'. Doktora Tezi, İstanbul Teknik Üniversitesi, Fen Bilimleri Enstitüsü, İstanbul, 1998.

[6] Gülenaz N. Batılılaşma dönemi İstanbul'unda Hanlar ve Pasajlar)2010-86). İstanbul: İTO Yayınları, 2010.

[7] Güran, C. Türk Hanlarının Gelişimi ve İstanbul Hanlarının Mimarisi. İstanbul: Vakıflar Genel Müdürlüğ̈̈ Yayınları, 1976.

[8] Köroğlu, N. 'XIX. Yüzyıl ve XX. Yüzyıl Başı Eminönü’nde Osmanlı Büro Hanları'. Yüksek Lisans Tezi, Yıldız Teknik Üniversitesi, İstanbul, 2004.

[9] ÖZKAN, A. 'Eminönü Hanlar Bölgesinin Cumhuriyet’ten Günümüze İzlenen Değişimi ve Yeniden Değerlendirilmesinde Öncelikli Bölgenin Saptanması'. Yüksek Lisans Tezi, İstanbul Teknik Üniversitesi, İstanbul, 2004.

[10] AS Mimarlık ve Restorasyon Ofisi tarafından hazırlanan rölöve, restitüsyon ve restorasyon projeleri ile raporları

[11] Encümen Kurulu Fotoğraf Arşivi

[12] Fatih Belediyesi Fotoğraf Arşivi

[13] W. Marklin \& Co. Damgalı bölge haritası

[14] Goad Haritası (1905)

[15] Pervititch Haritas1(1940)

[16] Indicateur Ottoman Illustre (1880-1883)

[17] Indicateur Oriental (1887-1888)

[18] Annuaire Oriental (1889-1930)

[19] Şark Y1llıkları (1931-1945) 